\title{
Treatment of biogas produced in anaerobic reactors for domestic wastewater: odor control and energy/resource recovery
}

\author{
Adalberto Noyola ${ }^{1, *}$, Juan Manuel Morgan-Sagastume ${ }^{1} \&$ Jorge E. López-Hernández $^{2}$ \\ ${ }^{1}$ Instituto de Ingeniería, UNAM, Circuito Escolar, Ciudad Universitaria, Coyoacán, 04510, México D.F., \\ México; ${ }^{2}$ IBTech, Av. Aztecas 479, Col. Ajusco, Coyoacán, 04300, México D.F., México; (*author for \\ correspondence: e-mail: noyola@pumas.iingen.unam.mx; phone: +52-55-56233662; fax: +52-55-56162798)
}

Key words: anaerobic sewage treatment, biogas, biogas utilization, denitrification, hydrogen sulfide, Kyoto protocol, methane, odor control

\begin{abstract}
Anaerobic municipal wastewater treatment in developing countries has important potential applications considering their huge lack of sanitation infrastructure and their advantageous climatic conditions. At present, among the obstacles that this technology encounters, odor control and biogas utilization or disposal should be properly addressed. In fact, in most of small and medium size anaerobic municipal treatment plants, biogas is just vented, transferring pollution from water to the atmosphere, contributing to the greenhouse gas inventory. Anaerobic municipal sewage treatment should not be considered as an energy producer, unless a significant wastewater flow is treated. In these cases, more than half of the methane produced is dissolved and lost in the effluent so yield values will be between 0.08 and $0.18 \mathrm{~N} \mathrm{~m}^{3}$ $\mathrm{CH}_{4} / \mathrm{kg}$ COD removed. Diverse technologies for odor control and biogas cleaning are currently available. High pollutant concentrations may be treated with physical-chemical methods, while biological processes are used mainly for odor control to prevent negative impacts on the treatment facilities or nearby areas. In general terms, biogas treatment is accomplished by physico-chemical methods, scrubbing being extensively used for $\mathrm{H}_{2} \mathrm{~S}$ and $\mathrm{CO}_{2}$ removal. However, dilution (venting) has been an extensive disposal method in some small- and medium-size anaerobic plants treating municipal wastewaters. Simple technologies, such as biofilters, should be developed in order to avoid this practice, matching with the simplicity of anaerobic wastewater treatment processes. In any case, design and specification of biogas handling system should consider safety standards. Resource recovery can be added to anaerobic sewage treatment if methane is used as electron donor for denitrification and nitrogen control purposes. This would result in a reduction of operational cost and in an additional advantage for the application of anaerobic sewage treatment. In developing countries, biogas conversion to energy may apply for the clean development mechanism (CDM) of the Kyoto Protocol. This would increase the economic feasibility of the project through the marketing of certified emission reductions (CERs).
\end{abstract}

\section{Introduction}

Among the well-known advantages of anaerobic digestion - low energy requirements, limited production of sludge and biogas generation - the latter is far from being exploited. Moreover, one of its main drawbacks - bad odor - has not been properly controlled in many anaerobic digestion facilities. This general diagnostic is particularly accurate in the case of the anaerobic treatment of domestic wastewater. Additionally, in most of the small anaerobic municipal treatment plants 
biogas is just vented, transferring pollution from water to the atmosphere and contributing to the greenhouse gas inventory.

At present, modern anaerobic technologies are widely applied for industrial wastewater treatment; however, their applications for domestic and municipal sewage treatment are still very limited. Developing countries, many in warm climate regions, have an enormous lack of sanitation facilities, so there is a huge potential application of anaerobic sewage treatment, considering its low-operational and maintenance costs and its matching with sustainability criteria (Noyola 2004). In order to favor a wider adoption of anaerobic processes and to get this potentiality into the real world, odor control and biogas utilization should be properly addressed.

Domestic wastewaters are not well suited for conventional anaerobic treatment. The low organic matter concentration and ambient temperature must be handled with modern technologies, such as the upflow anaerobic sludge blanket reactor (UASB) and anaerobic fixed film reactors. However, typical COD content in sewage will still produce a low amount of biogas and water temperatures below $20^{\circ} \mathrm{C}$ will seriously limit the application of the process. On the other hand, odors will be there, due to some end products of the anaerobic digestion, such as sulfides. In some places, where water supply is rich in sulfates, the entire sewage system will be a source of odors.

In this paper, treatment methods for biogas conditioning and odor control are reviewed.
Practical aspects for biogas handling and utilization are also briefly presented.

\section{Biogas in anaerobic municipal wastewater treatment}

Biogas is a mixture of gases produced during the anaerobic digestion of organic matter. It is generally composed of $60-65 \%$ methane $\left(\mathrm{CH}_{4}\right)$ and $35-40 \%$ carbon dioxide $\left(\mathrm{CO}_{2}\right)$. Minor constituents are hydrogen sulfide $\left(\mathrm{H}_{2} \mathrm{~S}\right)$, nitrogen $\left(\mathrm{N}_{2}\right)$, hydrogen $\left(\mathrm{H}_{2}\right)$ and traces of oxygen $\left(\mathrm{O}_{2}\right)$, carbon monoxide $(\mathrm{CO})$, ammonia $\left(\mathrm{NH}_{3}\right)$, argon $\left(\mathrm{Ar}_{2}\right)$ and other volatile organic compounds (VOC) (Constant et al. 1989). The composition of biogas will depend on the type and concentration of organic matter to be digested, on the physicochemical conditions in the digester $(\mathrm{pH}$, alkalinity, temperature) and on the presence of other anions such as sulfates and nitrates.

Some important properties of biogas as a fuel (considering a $60 \% \mathrm{CH}_{4}$ content) are (Constant et al. 1989): minimal calorific value of $21.5 \mathrm{MJ} /$ $\mathrm{m}^{3}$, stoechiometric air to fuel ratio of 5.71, flame velocity of $25 \mathrm{~cm} / \mathrm{s}$, minimum auto-ignite temperature of $600^{\circ} \mathrm{C}$, flammable biogas to air mixture between 8.3 and $20 \% \quad\left(5-12 \% \quad \mathrm{CH}_{4}\right.$ in air mixture); biogas will not burn if more than $75 \%$ of $\mathrm{CO}_{2}$ is present. Methane is lighter than air (gas density of methane is 0.55 relative to air), so in case of leaks, it will not remain on the ground and will migrate to upper spaces. Table 1 presents an energy comparison of methane, biogas and other common fuels.

Table 1. Minimum calorific values of biogas and other fuels and equivalence to methane (after Constant et al. 1989)

\begin{tabular}{|c|c|c|c|c|}
\hline Fuel & $\mathrm{MJ} / \mathrm{kg}$ & $\mathrm{MJ} / \mathrm{N} \mathrm{m}^{3}$ & $\mathrm{MBTU} / \mathrm{Nm}^{3}$ & Volumetric equivalence to $\mathrm{CH}_{4}$ \\
\hline Methane & 50.0 & 35.9 & 0.0340 & 1 \\
\hline Purified biogas $(90 \%)$ & 45.0 & 32.3 & 0.0306 & 0.9 \\
\hline Biogas $(60 \%)$ & 30.0 & 21.5 & 0.0203 & 0.6 \\
\hline Butane & 45.7 & 118.5 & 0.1123 & 3.3 \\
\hline Propane & 46.4 & 90.9 & 0.08617 & 2.5 \\
\hline Methanol & 19.9 & $15.9 \times 10^{3}$ & 15.0732 & 442.9 \\
\hline Ethanol & 26.9 & $21.4 \times 10^{3}$ & 20.2872 & 596.1 \\
\hline Gasoline & 45.0 & $33.3 \times 10^{3}$ & 31.5684 & 927.6 \\
\hline Diesel & 42.1 & $34.5 \times 10^{3}$ & 32.7060 & 961.0 \\
\hline
\end{tabular}

$\mathrm{Nm}^{3}$ : volume at normal temperature and pressure: $273^{\circ} \mathrm{K}$ and $1 \mathrm{~atm}$.

MBTU: Mega British Thermal Unities. 
This general biogas composition changes when a diluted wastewater, such as domestic sewage, is treated. Anaerobic digestion of domestic wastewater will produce a mixture of methane (70-80\%), nitrogen (10-25\%) and carbon dioxide $(5-10 \%)$ greatly influenced by the operational temperature (Noyola et al. 1988). The high nitrogen fraction in biogas produced from domestic wastewaters is due to the $\mathrm{N}_{2}$ dissolved in the sewage; once in the anaerobic reactor, it is stripped to the gaseous phase.

Moreover, low substrate means low methane production. In fact, as previously mentioned, anaerobic municipal sewage treatment should not be considered as an energy producer, unless a significant wastewater flow is treated. Actual methane yields are well below the theoretical value $\left(0.35 \mathrm{~N} \mathrm{~m}^{3} / \mathrm{kg}\right.$ COD removed; $\mathrm{Nm}^{3}$ means volume at normal temperature and pressure: $273^{\circ} \mathrm{K}$ and $1 \mathrm{~atm}$ ); more than half of the methane produced is dissolved and lost in the effluent and a fraction of COD, depending on the raw waste sulfate concentration, would be used by the sulfate reducing bacteria. The expected methane yield will thus depend on COD and sulfate concentrations in the sewage, as well as on water temperature; at higher temperature, less methane will be dissolved, as stated by Henry's law constants. As a result, methane yields values for anaerobic sewage treatment will be between 0.08 and $0.18 \mathrm{Nm}^{3} / \mathrm{kg}$ COD removed (Noyola et al. 1988).

\section{Odor and hydrogen sulfide generation in anaerobic wastewater treatment}

Odor can be defined as a stimulus of olfactory cells in the presence of specific compounds including volatile organic compounds (VOCs) and volatile inorganic compounds (VICs). In general, the most common odor problems are caused by mixtures of low concentrations of highly volatile compounds with very low threshold detection limits in air. Many industry branches produce gases which contain odorous VOCs or VICs. Those gases can be generated in process industries as synthetic flavoring, paint and dye, paper mills, pharmaceuticals, refineries, slaughterhouses, yeast and alcohol factories, sewage treatment works, solid waste composting works etc (Mukhopadhyay \& Moretti 1993).
Volatile compounds responsible for unpleasant or aggressive odors in sewage works and treatment facilities are produced mainly by microbial mediated organic matter decay. Many of the malodorous compounds are perceived at very low concentrations, of the order of parts per trillion. Carlson \& Leiser (1966) classified bad odors according to the following categories:

(a) inorganic gases such as hydrogen sulfide $\left(\mathrm{H}_{2} \mathrm{~S}\right)$ and ammonia $\left(\mathrm{NH}_{3}\right)$,

(b) organic acidic compounds such as acetic, propionic, butyric and lactic acids,

(c) highly toxic compounds such as skatole, phenols and mercaptans,

(d) amines such as cadaverine and putrescine.

Hydrogen sulfide is produced in an anaerobic environment mainly by sulfate reduction. Sulfates may be present in municipal sewage due to collection of industrial wastes rich in this anion (usually added as sulfuric acid in the production process) or to natural content in water supply.

Odorous organic compounds that has been found in wastewater treatment plants are carbon oxysulfide (COS), carbon disulfide $\left(\mathrm{CS}_{2}\right)$, mercaptanes of low molecular weight (R-SH), thiophenes $\left(\mathrm{C}_{4} \mathrm{H}_{4} \mathrm{~S}\right)$, dimethylsulfide $\left(\left(\mathrm{CH}_{3}\right)_{2} \mathrm{~S}\right)$, dimethyldisulfide $\left(\left(\mathrm{CH}_{3}\right)_{2} \mathrm{~S}_{2}\right)$ and dimethyltrisulfide $\left(\left(\mathrm{CH}_{3}\right)_{2} \mathrm{~S}_{3}\right)$ (Allen \& Phatak 1993). Other odorous molecules include mercaptans, ammonia, inorganic and organic amines, organic acids, aldehydes and ketones. In this environment, $\mathrm{H}_{2} \mathrm{~S}$ possesses such characteristic odor that it generally masks the scent of other organic sulfide compounds (Bhatia 1978; Smet \& Van Langenhove 1998). For this reason, $\mathrm{H}_{2} \mathrm{~S}$ is the most characteristic bad odor constituent in biogas and in the environment of anaerobic digesters and wastewater treatment facilities in general (Carlson \& Leiser 1966; Cho et al. 1992; Allen \& Phatak 1993; Fernandez-Polanco et al. 1996; Martínez \& Zamorano 1996; Metcalf \& Eddy 2003). In fact, many research works on odor control consider $\mathrm{H}_{2} \mathrm{~S}$ as the reference compound.

Hydrogen sulfide is also an important hazardous compound with the following characteristics: Inflammable and poisonous gas, perceived in air at concentrations of $0.02-0.13$ ppmv. It is a highly toxic gas and it can be lethal. Exposure of human beings to low $\mathrm{H}_{2} \mathrm{~S}$ concentrations can 
cause headaches, nausea and irritation of eyes and throat as well as rhinitis, Keratoconjuntivitis, photophobia, intense cough and bronchopneumonia. High concentrations can cause paralysis of the breathing system, loss of knowledge and death. Exposition of few minutes to $\mathrm{H}_{2} \mathrm{~S}$ concentrations exceeding $0.2 \%$ (2000 ppmv) can be lethal to human beings. $\mathrm{H}_{2} \mathrm{~S}$ is a corrosive compound and attacks different materials (iron, copper, cement etc.) as well as harmful to vegetation in general (Merck 1996).

The concentrations of $\mathrm{H}_{2} \mathrm{~S}$ found in treatment plants can vary considerably depending on the type of processes involved and on the characteristics of the wastewater. In this sense, Rands et al. (1981) found $\mathrm{H}_{2} \mathrm{~S}$ concentrations in municipal treatment works between 45 and 537 ppmv and up to $1000 \mathrm{ppmv}$ in the biogas from anaerobic sludge digesters. On the other hand, Pomeroy (1982), Lang \& Jager (1992) and Webster et al. (1996) reported concentrations of $\mathrm{H}_{2} \mathrm{~S}$ between 0.1 and 10 ppmv. Other compounds associated with odors in wastewater facilities are dimethylsulfide and methyl mercaptan. Cho et al. (1992) and Allen \& Phatak (1993) found these VOCs at concentrations between 5 and 40 ppmv.

Hydrogen sulfide is a highly soluble gas (Henry's constant: $2582 \mathrm{mLgas} /($ Lwater atm) at $20{ }^{\circ} \mathrm{C}$ ) that dissociates in water according to the following equilibrium reactions:

$$
\begin{gathered}
\mathrm{H}_{2} \mathrm{~S} \text { (gas) } \uparrow \longleftrightarrow \mathrm{H}_{2} \mathrm{~S} \text { (liq.) } \\
\mathrm{H}_{2} \mathrm{~S} \text { (liq.) } \longleftrightarrow \mathrm{HS}^{-}+\mathrm{H}^{+} \quad \mathrm{K}_{\mathrm{a}_{1}}=1 \times 10^{-7} \quad \mathrm{pK}_{\mathrm{a}}=7.0
\end{gathered}
$$

$$
\mathrm{HS}^{-} \longleftrightarrow \mathrm{S}^{2-}+\mathrm{H}^{+} \quad \mathrm{K}_{\mathrm{a} 2}=1.3 \times 10^{-13} \quad \mathrm{pK}_{\mathrm{a}}=12.9
$$

Odor problems associated with $\mathrm{H}_{2} \mathrm{~S}$ are thus highly dependent on the wastewater $\mathrm{pH}$. When the $\mathrm{pH}$ is under 5 , practically all sulfides are as $\mathrm{H}_{2} \mathrm{~S}$ and in physical equilibrium with the gas phase; at $\mathrm{pH} 10$, sulfides are dissolved as $\mathrm{HS}^{-}$. At $\mathrm{pH}$ around 7 , the common operational value in anaerobic wastewater treatment, $\mathrm{H}_{2} \mathrm{~S}$ and $\mathrm{HS}^{-}$ will be present in solution close to an equal ratio (50\% for each).

\section{Available treatment options for biogas treatment and odor control}

A general classification of common technologies applied for $\mathrm{VOC}, \mathrm{H}_{2} \mathrm{~S}$ and odor control is presented in Figure 1. Some of them are also used for $\mathrm{CO}_{2}$ removal as its separation may be accomplished together with $\mathrm{H}_{2} \mathrm{~S}$ (absorption, adsorption and membrane technologies). This classification is based on the nature of each control technology, that is, physical, chemical or biological. Generally, physical processes are mostly applied for gas streams where the flow and pollutant concentration are high. Important parameters for a proper application of a biological treatment are the solubility and the biodegradability of the compounds to be removed. The most important advantage of biological treatment methods over physical and chemical technologies is the fact that biological processes can be operated at local temperature and pressure. Biological purification facilities are inexpensive compared with most of the physical-chemical treatments and also are ecologically cleaner. However, to make a good selection of a treatment method, flow rate, type of pollutant and its concentration must be considered. Other important factors that determine the selection are temperature, oxygen content of the waste gas, stream composition, solubility, production time pattern, and investment and maintenance requirements. The occurrence of secondary environmental impacts and pollution transfer must be evaluated too.

Some technologies mentioned in Figure 1 may be useful for biogas treatment; others are suitable for odor control. Figure 2 shows the common application of each type of technology based on pollutant concentration and air or gas flow. As can be observed, for high pollutant concentrations physical-chemical processes are preferred instead of biological ones. In general terms, biogas treatment is accomplished by physicochemical methods, while biological processes are used basically for odor control as a mitigation technology to prevent negative impacts on the treatment facilities or nearby areas. Biological methods are usually used when the concentration of odorous compounds are low and susceptible to be treated aerobically.

An economic comparison between several options for control of gaseous emissions is presented in Table 2. 


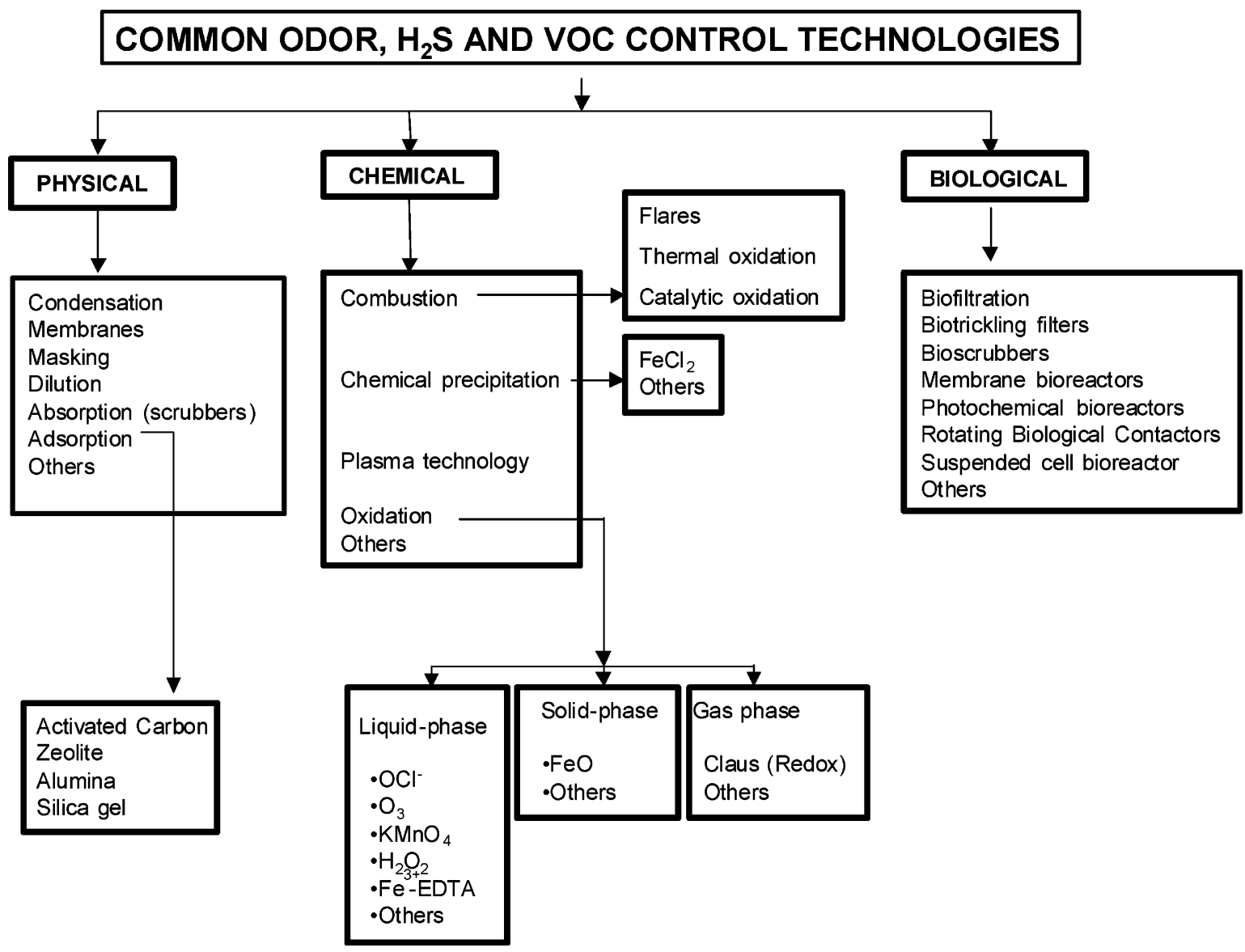

Figure 1. Classification of common technologies for VOC and odor control (after Revah \& Morgan-Sagastume 2005).

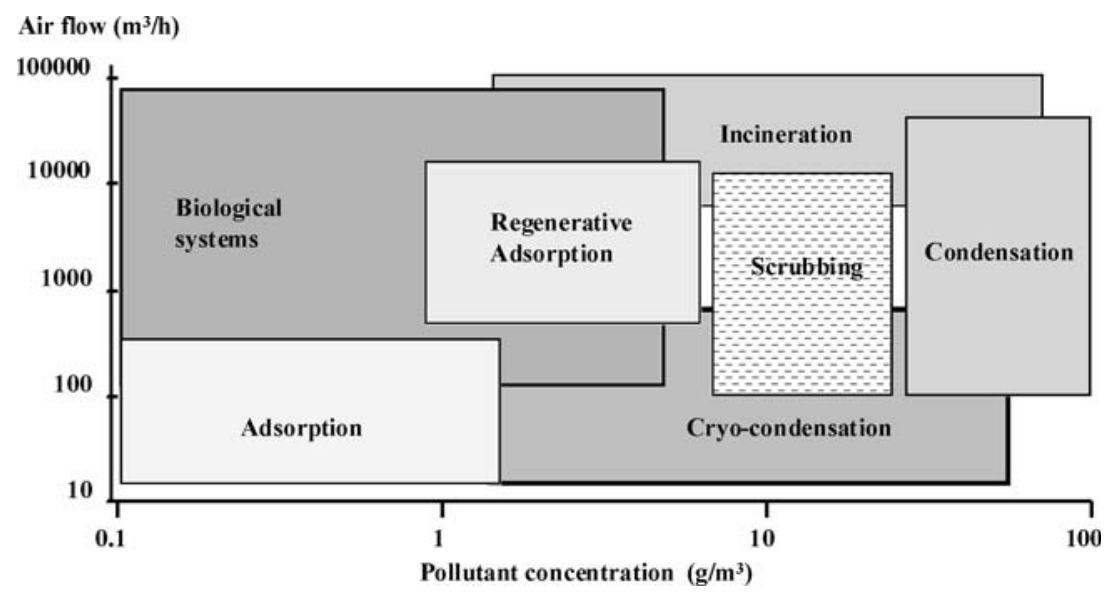

Figure 2. Applicability of various gaseous pollution control technologies based on gas flow rates and concentrations to be treated (adapted from van Groenestijn \& Hesselink 1993). 
Table 2. Cost comparison for some common gaseous treatment for odor control (Revah \& Noyola 1996)

\begin{tabular}{ll}
\hline Treatment option & Cost USD $/ \mathrm{m}^{3}$ \\
\hline Biofilter & $0.1-3.0$ \\
Bioscrubber & $1.5-3.0$ \\
Chemical scrubber & $0.6-12$ \\
Combustion & $1.5-15$ \\
Catalytic treatment & $1.5-12$ \\
\hline
\end{tabular}

\subsection{Physical-chemical methods}

\subsubsection{Dilution}

Dilution can occur by the addition of sufficient fresh air to reduce the odor concentration below the threshold level (Corbitt 1990). This is useful in certain applications to reduce explosion risk. Tall stacks and heated gas streams have been successfully used by the industry for dilution of large volumes of gases by plume dispersion. The stack systems may be used for low concentrations of odor and can be a second-stage system following another control method. Dilution cannot be considered as a treatment method, since pollution remains without treatment. However, dilution has been an extensive method in anaerobic plants treating municipal wastewaters and where the size of the plant and its economical situation do not allow a proper treatment method for biogas treatment. Simple technologies should be developed in order to avoid this practice.

\subsubsection{Condensation}

Condensation can occur by lowering the gas stream temperature at constant pressure or increasing the gas stream pressure at constant temperature (Planker 1998; Waldrop 1998; Kennes et al. 2001; Bell, 1988). It is generally applied to treat effluent streams consisting of a condensable pollutant vapor and a noncondensable gas. There are basically two types of condensers: surface and direct contact. Surface condensers are generally shell and tube heat exchangers where coolant flows inside the tubes and the gas stream with VOCs flows outside the tubes. Contact condensers operate by spraying a cool liquid directly into a gas stream to cool and condense the VOCs.

\subsubsection{Membranes}

VOCs may be removed from gas streams by semi-permeable membranes (Kennes et al. 2001; Mukhopadhya \& Moretti 1993). This barrier is made of synthetic polymers wrapped around a perforated central collection pipe. The driving force for the gas flow is the pressure gradient across the membrane using a vacuum pump. In odor control applications, membrane is permeable to VOCs but not air, therefore, the polluting compounds pass through the membrane while the purified air stream is released to the atmosphere. Membranes made of acetate and cellulose have been used for biogas cleaning, as they may separate both $\mathrm{CO}_{2}$ and $\mathrm{H}_{2} \mathrm{~S}$ from methane, but pressures higher than 25 bars should be applied.

\subsubsection{UV oxidation}

Ultraviolet (UV) radiation is a process that is based on the transfer of electromagnetic energy from a source (lamp) to the organic matter (Kennes et al. 2001; Mukhopadhya \& Moretti 1993; Qasim 1999). This is an emerging technology for the control of VOCs that uses oxygen based oxidants like ozone, peroxide, $\mathrm{OH}^{-}$, and $\mathrm{O}^{2-}$ radicals to convert VOCs into $\mathrm{CO}_{2}$ and $\mathrm{H}_{2} \mathrm{O}$ in the presence of ultraviolet light, enhancing the activity of oxygen-based oxidants. The primary source of UV energy is the low pressure mercury lamp. It is almost universally accepted as the most efficient and effective source of UV radiation. The lamps are tubes, typically $0.75-1.5 \mathrm{~m}$ in length and $1.5-2.0 \mathrm{~m}$ in diameter. Approximately $35-40 \%$ of the energy is converted to light, and approximately $85 \%$ of light has a wavelength of $253.7 \mathrm{~nm}$.

\subsubsection{Plasma}

Plasma is a mixture of free moving electrons and positively charged ions (Van Groenestijn 2001b). Non-thermal plasmas are an excellent source of gas phase free radicals $\left(\mathrm{O}^{2-}, \mathrm{OH}^{-}\right.$and $\left.\mathrm{H}^{+}\right)$and other active species useful for destroying pollutants. Reactive species in non-thermal plasma such as $\mathrm{OH}^{-}$radicals, $\mathrm{O}_{3}$ molecules, and $\mathrm{O}$ and $\mathrm{N}$ atoms can react with odorous and toxic gases and convert them into non-odorous and non-toxic molecules. Plasma can be generated in a medium between two electrodes where a high voltage AC $(10-30 \mathrm{kV})$ is applied for a very short time 
(1-10 ms). The plasmas can be generated by dielectric barrier discharge or an electron beam. Dielectric barrier discharge, also called corona discharge, utilizes a dielectric material between the discharge gap and one of the two discharge electrodes used. On the other hand, the electron beam technology is based on an electron gun that shoots high energetic electrons to a target object. The use of non-thermal plasmas for gas pollution treatment has high-potential application, but is still in its early stages of research and development. Plasma technology can be classified as an electro-chemical process.

\subsubsection{Adsorption}

Adsorption refers to the process where gaseous VOC molecules contact the surface of a solid adsorbent and bond via weak intermolecular forces (Kennes et al. 2001; Mukhopadhya \& Moretti 1993; Smet \& Van Langenhove 1998). Activated carbon is the most common adsorbent in use today for VOC treatment. Others include silica gel, alumina and zeolite. They are 'activated' by heat under controlled conditions at high temperatures to remove volatile non-carbon constituents and increase the surface area. Several types of carbon adsorption units are commercially available, but the most common is the fixed regenerative bed. It has two or more beds (columns) of activated carbon working in parallel. Continuous system operation is possible by the concurrent adsorption by at least one bed and desorption by the other beds. Adsorbent regeneration is accomplished by volatilization of the adsorbed compounds either by increased temperature with steam or by lowering the bed pressure. Activated carbon has been used for $\mathrm{CO}_{2}$ and $\mathrm{H}_{2} \mathrm{~S}$ removal from biogas.

\subsubsection{Scrubbing}

In a scrubber, transfer of pollutants from a gas stream to an aqueous phase is accomplished by intense contacting of the polluted gas with water or an absorbent solution within a packed column (Figure 3). Mass transfer depends on the concentration, the air/water partitioning (Henry law) coefficient and the mass transfer resistance of the scrubber system. Scrubbing has been used extensively for $\mathrm{H}_{2} \mathrm{~S}$ and $\mathrm{CO}_{2}$ removal from the biogas prior to its use. Some specific absorbent compositions are presented:

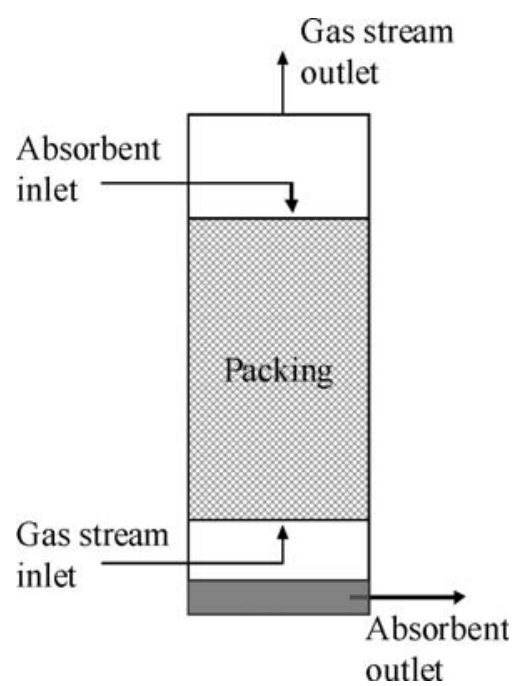

Figure 3. Schematic view of a general scrubber system.

4.1.7.1. Caustic scrubbing. Absorption is favored by highly alkaline conditions (Mansfield et al. 1992). A gas stream containing the pollutant is fed to an absorption tower with high alkalinity (i.e., $\mathrm{NaOH} 50 \%$ by weight, $\mathrm{pH}>12$ ). The absorbent is not regenerated in this process which requires high reagent consumption and a proper final disposal of the spent solution.

4.1.7.2. Regenerative gas scrubbing. As an example of this process, $\mathrm{H}_{2} \mathrm{~S}$ removal may be accomplished according to the following reaction (Smet \& Van Langenhove 1998; West 1983):

$$
\mathrm{R}_{2} \mathrm{NH}+\mathrm{H}_{2} \longleftrightarrow \mathrm{R}_{2} \mathrm{NH}_{2} \mathrm{HS}+\text { heat }
$$

There are different types of absorbents which are acids or bases. During $\mathrm{H}_{2} \mathrm{~S}$ scrubbing process, $\mathrm{H}_{2} \mathrm{~S}$ as well as $\mathrm{CO}_{2}$ are discharged as exhaust product, so additional treatment processes would be needed before final disposal. The heat produced by the exothermic reaction during the absorption step is used to preheat the absorbent in the desorption step. Usually, the absorption tower works at low or ambient temperature to favor solubilization while desorption is favored at higher temperatures. By this means, the absorbent can be regenerated. Absorbants commonly used include mono-ethanolamine, di-ethanolamine, di-glycolamine, methyl-di-ethanolamine, di-isopropanolamine, hot potassium carbonate, methanol, propylene carbonate, N-methyl-2-pyrrolidone. 
4.1.7.3. Chemical precipitation with $\mathrm{FeCl}_{2}$. The $\mathrm{H}_{2} \mathrm{~S}$ contained in the gas stream is absorbed in a scrubber with a solution of $\mathrm{FeCl}_{2}$ and the dissolved $\mathrm{H}_{2} \mathrm{~S}$ is precipitated as $\mathrm{FeS}$ according with the following reaction (Särner 1990):

$$
\mathrm{Fe}_{2}^{+}+\mathrm{H}_{2} \mathrm{~S} \rightarrow \mathrm{FeS}+2 \mathrm{H}^{+}
$$

The $\mathrm{Fe}_{2}^{+}$is not regenerated during the process which means considerable reagent consumption.

4.1.7.4. Chlorine oxidation. After $\mathrm{H}_{2} \mathrm{~S}$ has been absorbed in a scrubbing tower, it may be oxidized with sodium hypochlorite to produce either elemental sulfur or sulfate, depending on $\mathrm{pH}$, according to the following reactions (Cadena \& Peters 1988):

$$
\begin{aligned}
& \mathrm{HS}^{-}+\mathrm{OCl}^{-} \rightarrow \mathrm{S}^{0}+\mathrm{OH}^{-}+\mathrm{Cl}^{-} \text {at } \mathrm{pH}<7.5 \\
& \mathrm{HS}^{-}+4 \mathrm{OCl}^{-} \rightarrow \mathrm{SO}_{4}^{2-}+\mathrm{H}^{+}+4 \mathrm{Cl}^{-} \text {at } \mathrm{pH}>7.5
\end{aligned}
$$

Chlorine is not regenerated in the process, so it may result in a high operational cost. Moreover, in the presence of organic compounds, chlorine oxidation is not attractive due to the formation of undesirable organic chloride compounds.

4.1.7.5. Ozone oxidation. $\mathrm{H}_{2} \mathrm{~S}$ or VOCs are dissolved in water within a scrubbing tower and then they are oxidized by ozone (Chen \& Morris 1972). The sulfur oxidation is practically instantaneous and due to ozone instability in situ generation is required. Ozone is a powerful oxidant but is expensive.

$$
\begin{gathered}
\mathrm{HS}^{-}+\mathrm{O}_{3} \rightarrow \mathrm{S}^{0}+\mathrm{OH}^{-}+\mathrm{O}_{2} \\
\mathrm{HS}^{-}+4 \mathrm{O}_{3} \rightarrow \mathrm{SO}_{4}^{2-}+4 \mathrm{O}_{2}+\mathrm{H}^{+}
\end{gathered}
$$

4.1.7.6. Potassium permanganate oxidation. After $\mathrm{H}_{2} \mathrm{~S}$ is scrubbed, it can be oxidized using potassium permanganate (Cadena \& Peters 1988). This method is not attractive since it has a high cost and the manganese oxide must be adequately disposed of to avoid a negative environmental impact. In addition, different sulfur compounds are produced depending on $\mathrm{pH}$.

$$
\begin{aligned}
& 3 \mathrm{H}_{2} \mathrm{~S}+2 \mathrm{KMnO}_{4} \rightarrow 3 \mathrm{~S}^{0}+2 \mathrm{H}_{2} \mathrm{O}+2 \mathrm{MnO}_{2} \\
& +2 \mathrm{KOH} \text { at } \mathrm{pH}<7.5
\end{aligned}
$$

$$
\begin{aligned}
& 3 \mathrm{H}_{2} \mathrm{~S}+8 \mathrm{KMnO}_{4} \rightarrow 8 \mathrm{MnO}_{2}+3 \mathrm{~K}_{2} \mathrm{SO}_{4}+2 \mathrm{H}_{2} \mathrm{O} \\
& \quad+2 \mathrm{KOH} \text { at } \mathrm{pH}>7.5)
\end{aligned}
$$

4.1.7.7. Hydrogen peroxide oxidation. The oxidation rate of sulfide with hydrogen peroxide is relatively slow (Cadena \& Peters 1988). Twenty to 30 min contact time is normally required for a complete reaction. The mechanisms of oxidation of $\mathrm{H}_{2} \mathrm{~S}$ by hydrogen peroxide are not well understood; however, it is suggested that direct oxidation of sulfide by hydrogen peroxide depends on the reaction with oxygen released during gradual decomposition of hydrogen peroxide. $\mathrm{H}_{2} \mathrm{~S}$ must be dissolved in water (scrubbing tower) prior to its oxidation.

$$
\begin{aligned}
& \mathrm{H}_{2} \mathrm{O}_{2}+\mathrm{H}_{2} \mathrm{~S} \rightarrow \mathrm{S}^{0}+2 \mathrm{H}_{2} \mathrm{O} \text { at } \mathrm{pH}<8.5 \\
& 2 \mathrm{H}_{2} \mathrm{O}_{2}+\mathrm{S}^{2-} \rightarrow \mathrm{SO}_{2}^{2-}+2 \mathrm{H}_{2} \mathrm{O} \text { at } \mathrm{pH}>8.5
\end{aligned}
$$

\subsubsection{Catalytic oxidation with $\mathrm{Fe}^{3+}$ (LO-CAT process)}

In this patented process, ferric and ferrous ions are chelated with EDTA to avoid precipitation as $\mathrm{FeOH}$ or $\mathrm{FeS}$ (Thomson 1980). This allows the ferric ion regeneration using air $\left(\mathrm{O}_{2}\right)$ so $\mathrm{H}_{2} \mathrm{~S}$ oxidation and reagent regeneration are simultaneous in two different columns.

$$
\begin{gathered}
\mathrm{H}_{2} \mathrm{~S}+2\left[\mathrm{Fe}^{3+}\right] \rightarrow \mathrm{S}^{0}+2\left[\mathrm{Fe}^{2+}\right]+2 \mathrm{H}^{+} \\
2\left[\mathrm{Fe}^{2+}\right]+0.5 \mathrm{O}_{2}+\mathrm{H}_{2} \mathrm{O} \rightarrow 2\left[\mathrm{Fe}^{3+}\right]+2 \mathrm{OH}^{-}
\end{gathered}
$$

\subsubsection{Oxidation with $\mathrm{FeO}$}

This treatment is based on the interaction of $\mathrm{H}_{2} \mathrm{~S}$ with a dry packed bed of $\mathrm{Fe}_{2} \mathrm{O}_{3}$ and $\mathrm{FeO}$ that may be in the form of iron residues (turnings, blast furnace), natural minerals or iron oxide embedded wood shavings (Constant et al. 1989). Diverse sulfur compounds are formed as reaction products. Regeneration may be done by oxidation with an air stream through the packed bed or in smaller applications, by exposing the spent material to the air in an open space. The regeneration reaction is exothermic, so some precautions should be taken. 
$\mathrm{H}_{2} \mathrm{~S}$ oxidation:

$$
\begin{aligned}
& \mathrm{Fe}_{2} \mathrm{O}_{3}+3 \mathrm{H}_{2} \mathrm{~S} \rightarrow \mathrm{Fe}_{2} \mathrm{~S}_{3}+3 \mathrm{H}_{2} \mathrm{O} \\
& \mathrm{FeO}+\mathrm{H}_{2} \mathrm{~S} \rightarrow \mathrm{FeS}+\mathrm{H}_{2} \mathrm{O}
\end{aligned}
$$

$\mathrm{Fe}_{2} \mathrm{O}_{3}$ and $\mathrm{FeO}$ regeneration:

$$
\begin{aligned}
& \mathrm{Fe}_{2} \mathrm{~S}_{3}+3 / 2 \mathrm{O}_{2} \rightarrow \mathrm{Fe}_{2} \mathrm{O}_{3}+3 \mathrm{~S}^{0} \\
& \mathrm{FeS}+0.5 \mathrm{O}_{2} \rightarrow \mathrm{FeO}+\mathrm{S}^{0}
\end{aligned}
$$

This method has been widely used for biogas cleaning in small and medium size facilities.

\subsubsection{Pressurized water}

This rather simple method has been used for $\mathrm{CO}_{2}$ and $\mathrm{H}_{2} \mathrm{~S}$ removal from biogas. A pressurized packed scrubber column is fed with water and biogas in a counter-current pattern, water being sprayed at the top. The spent water with high concentration of dissolved gases is regenerated at ambient pressure in another column or mixed tank, where $\mathrm{CO}_{2}$ and $\mathrm{H}_{2} \mathrm{~S}$ should be recovered or properly disposed of.

\subsection{Biological methods}

Biological gas treatment systems are based on the capacity of microorganisms, including bacteria, yeast and fungi, to transform certain organic and inorganic pollutants into compounds that have very low impact on health and environment. For odor control applications, pollutants are mixed in an air stream, so microbial degradation involved is generally oxidative in nature and end products are carbon dioxide, water, sulfate, and nitrate, depending on the odorous compound. This is not the case when biogas cleaning is the objective, as no oxygen is present on the mixture and addition of air should be avoided due to the risk of forming an explosive mixture. However, some biological process could be applied if a strict control of air addition can be guaranteed. This particular method should be developed for methane removal prior to biogas venting at small size anaerobic municipal sewage treatment facilities, where no reliable flare system can be applied due to the low biogas production. Moreover, considering the simplicity of biofilters, this technology would be in congruence with this type of wastewater treatment process. A methane and sulfide oxidizing bacterial consortium would make this technology feasible.

A combination of physical-chemical and biological processes may be applied for biogas treatment applications, if the undesirable compounds such as $\mathrm{H}_{2} \mathrm{~S}$ are transferred in a scrubber tower into a biologically active aqueous phase. In such case, the microorganisms will metabolize those compounds, as a source of nutrients or energy for growth and maintenance, producing more biomass and carbon dioxide, water, sulfate or sulfur, nitrate, etc. depending on the pollutant. The overall efficiency of the process is determined by the relative rates of the physical, chemical and biological processes involved.

Although the basic mechanisms are the same for all biological methods, there are different equipment configurations to achieve transfer of pollutants and their biodegradation.

\subsubsection{Biofilter}

In biofilters, an air mixture passes through a moist packed bed that contains microorganisms growing as a biofilm on the surface and crevices of the support (Figure 4). The biofilm activity is determined by its microbial density and the environmental conditions, such as temperature, nutrient availability, $\mathrm{pH}$ and humidity. The humidity of the biofilm is one of the critical aspects that should be controlled in order to maintain biological activity (Lang \& Jager 1992).

The supports can be either bioactive or inert. Natural bioactive supports, such as soil, peat,

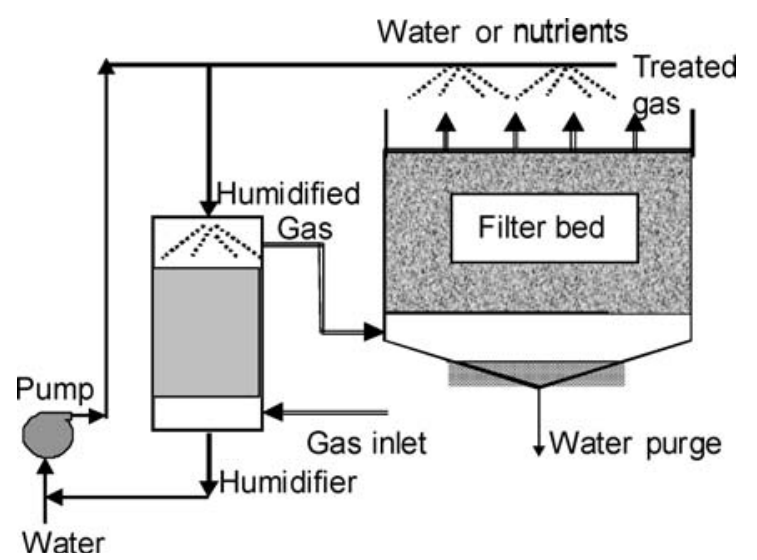

Figure 4. Schematic diagram of an open biofilter. 
compost, bark etc., can retain water and generally contain enough mineral nutrients to support an initial active microbial population (CardenasGonzalez et al. 1999). They are relatively inexpensive and easy to obtain and have been used for many applications. However, natural supports may degrade with time and loose their structure and water retaining capacity inducing channeling and the loss of performance (MorganSagastume et al. 2003a). In some cases, re-mixing the support with fresh material and nutrients allows recovery of activity, but eventually it will need to be entirely replaced (Morgan-Sagastume et al. 2003b). With proper maintenance, the support can be used for several years.

\subsubsection{Biotrickling filters}

In this device, polluted air is passed through a packed non-submerged column where liquid is continuously down-flow recirculated through the packing. The pollutant is first solubilized in the falling liquid film and transferred to the microorganisms that grow attached to the surface of these supports. The liquid provides moisture, nutrients, $\mathrm{pH}$ control to the biofilm and allows the removal of inhibiting products. Eventually, excess biomass is sloughed off by the trickling liquid and stable operation can be achieved.

The supports are inert packing materials, random or structured, which are similar to those used in traditional scrubbers (plastic Raschig or Pall rings and saddles) although others such as volcanic scoria or polyurethane foam have been tested (Van Groenestijn 2001b). The air may be directed upflow or downflow which is countercurrent or cocurrent with the liquid flow, respectively. To maintain low pressure drop and reduce clogging, the support should have high porosity and specific surface ratio lower than $400 \mathrm{~m}^{2} \mathrm{~m}^{-3}$.

\subsubsection{Rotating biological contactors}

Rotating biological contactors were developed initially for wastewater treatment In this device, polluted air passes through the headspace of an assembly of discs mounted on a rotating shaft that serve as biofilm support. The shaft is rotated (around $2 \mathrm{rpm}$ ) and the discs are partially submerged in water containing nutrients and other additives. The movement of the discs favors mass transfer and the control of the fixed biomass. Air can be fed tangentially to the disks or through perforations in a hollow shaft (Rudolf von Rohr \& Ruediger 2001).

\subsubsection{Bioscrubbers}

In bioscrubbers, pollutants in a gas phase are removed by absorption in a recycling water stream in a scrubber tower (Van Groenestijn 2001a). Subsequently this pollutant laden water is regenerated by microorganisms in a bioreactor with supplementary oxygen, and then returned to the contactor. Nutrient addition and $\mathrm{pH}$ are continually controlled in the bioreactor in order to maintain microbial growth and high activity. The excess biomass and byproducts are purged from the system. Scrubbers are designed to favor mass transfer from air to liquid phase, while maintaining a low pressure drop $\left(<3 \mathrm{~cm} \mathrm{H}_{2} \mathrm{O} / \mathrm{m}\right)$. The contactors can be packed towers, venturi scrubbers, spray towers, etc. Bioreactors are usually activated sludge systems.

\subsubsection{Membrane bioreactors}

In a membrane bioreactor, the pollutant in the gas phase is transferred through a membrane to a biofilm attached on the other side of the barrier, where nutrients and oxygen are provided. The basic configurations are hollow fibers and flat sheets. In hollow fibers the gas is usually passed through the lumen of the fiber and the biomass is on the shell side. These reactors have been used for other waste treatment applications where the stream conditions exclude the possibility of direct contact with the biomass (Van Groenestijn \& Hesselink 1993; Ergas 2001).

Membranes can be made of very diverse materials and have different chemical and physical properties (solubility, selectivity, mechanical strength, pore size, thickness and porosity). A distinct characteristic of the membrane bioreactors is the fact that the polluted gaseous stream and the biomass is physically segregated which allows the use of waste gas treatment in certain extreme applications such as indoor air.

\subsubsection{Suspended cell bioreactor}

In the suspended cell bioreactors the polluted air is bubbled in the bulk liquid containing suspended 
microorganisms. Several configurations can be proposed (Bielefeldt 2001). The characteristics of the reactor, such as biomass concentration, air feed and sparger design, are generally imposed by the requirements of the wastewater treatment. In an activated sludge process, the biological activity in the mixed liquor may be used to simultaneously treat the wastewater and the dissolved polluted air.

\subsection{Microorganisms of particular interest for $\mathrm{H}_{2} \mathrm{~S}$ removal}

Among the $\mathrm{H}_{2} \mathrm{~S}$ oxidizing microorganisms, Thiobacillus seems to be particularly suited for engineering applications due to its simple nutritious requirements, its high effectiveness and resistance to toxic substances and the wide $\mathrm{pH}$ interval it can tolerate (Cadenhead \& Sublette 1990). The most common reaction is a direct oxidation of sulfide to sulfur and sulfates by means of oxygen provided by air. In other cases (Thiobacillus denitrificans) nitrate reduction to $\mathrm{N}_{2}$ allows the oxidation of sulfide to sulfate. Particularly, Thiobaillus ferroxidans raises a very simple and effective process for $\mathrm{H}_{2} \mathrm{~S}$ treatment in which the oxidant is regenerated by the microorganisms. Some relevant microorganisms are the following:

\subsubsection{Chlorobium limicola - thiosulfatophilum}

$$
2 \mathrm{H}_{2} \mathrm{~S}+\mathrm{CO}_{2}+h v \rightarrow 2 \mathrm{~S}^{0}+\left(\mathrm{CH}_{2} \mathrm{O}\right)+\mathrm{H}_{2} \mathrm{O}
$$

An autotrophic anaerobic microorganism that uses light as energy which may be a disadvantage due to the associated costs (Cork \& Ma 1982). The system does not depend on oxygen, as oxidation of $\mathrm{H}_{2} \mathrm{~S}$ takes place in an anaerobic medium in the presence of $\mathrm{CO}_{2}$. The system favors growth of Chlorobium due to the high concentrations of $\mathrm{H}_{2} \mathrm{~S}$ in the reactor, which works like a bactericidal compound inhibiting the growth of other anaerobic bacteria that could compete, such as methanogens. The main advantage of this process are the useful reaction products that are obtained from $\mathrm{H}_{2} \mathrm{~S}$ and $\mathrm{CO}_{2}$.

\subsubsection{Xanthomonas sp. chain DY44}

Chemoheterotrophic aerobic microorganism reported by Cho et al. (1992). The $\mathrm{H}_{2} \mathrm{~S}$ oxidation product is identified as a polysulfide and is obtained at a maximum removal rate of $3.92 \mathrm{mmol}\left(\mathrm{H}_{2} \mathrm{~S}\right) / \mathrm{g}$ (dry cells $) \mathrm{h}$. The main advantage of this microorganism is based on its high growth rate, facilitating starting up and control of the population in a reactor. As sulfate is not produced, the decrease of $\mathrm{pH}$ and the consequent effects on the microbial consortia are not a problem.

\subsubsection{Thiobacillus denitrificans}

This chemoautotrophic facultative microorganism with simple nutritional requirement can grow in a heterotrophic environment. The use of these microorganisms has two disadvantages: the slow growth and the sulfate production that is accumulated in the reactor that may eventually inhibit the microorganism (Sublette \& Sylvester 1987; Ongcharit et al. 1990).

4.3.4. Thiobacillus thioparus, $\mathrm{T}$. versutus, $\mathrm{T}$. neopolitanus and $\mathrm{T}$. thioxidans These microorganisms have been used in pilot plants offering similar characteristic in their behavior. They do not have a clear advantage over Thiobacillus denitrificans, as their growth rates are lower, but they have a lower requirement of ammonium (Cadenhead \& Sublette 1990).

\subsubsection{Thiobacillus ferrooxidans}

The oxidation of the $\mathrm{H}_{2} \mathrm{~S}$ to $\mathrm{S}^{0}$ is carried out with ferric sulfate according to the reaction:

$$
\mathrm{H}_{2} \mathrm{~S}+\mathrm{Fe}_{2}\left(\mathrm{SO}_{4}\right)_{3} \rightarrow \mathrm{S}^{0}+2 \mathrm{FeSO}_{4}+\mathrm{H}_{2} \mathrm{SO}_{4}
$$

Ferric sulfate can be regenerated from ferrous sulfate using Thiobacillus ferrooxidans as follows:

$$
2 \mathrm{FeSO}_{4}+\mathrm{H}_{2} \mathrm{SO}_{4}+0.5 \mathrm{O}_{2} \rightarrow \mathrm{Fe}_{2}\left(\mathrm{SO}_{4}\right)_{3}+\mathrm{H}_{2} \mathrm{O}
$$

The first reaction is highly quantitative avoiding the discharge of $\mathrm{H}_{2} \mathrm{~S}$. The oxydation reagent is regenerated, so operational costs are reduced. Moreover, if sulfur is recovered, water would be the only by-product of the reactions. In general, the operation costs of this process, called BIOSR (Figure 5), are around one third of those of conventional processes such as scrubbers and adsorption columns. This arrangement avoids 


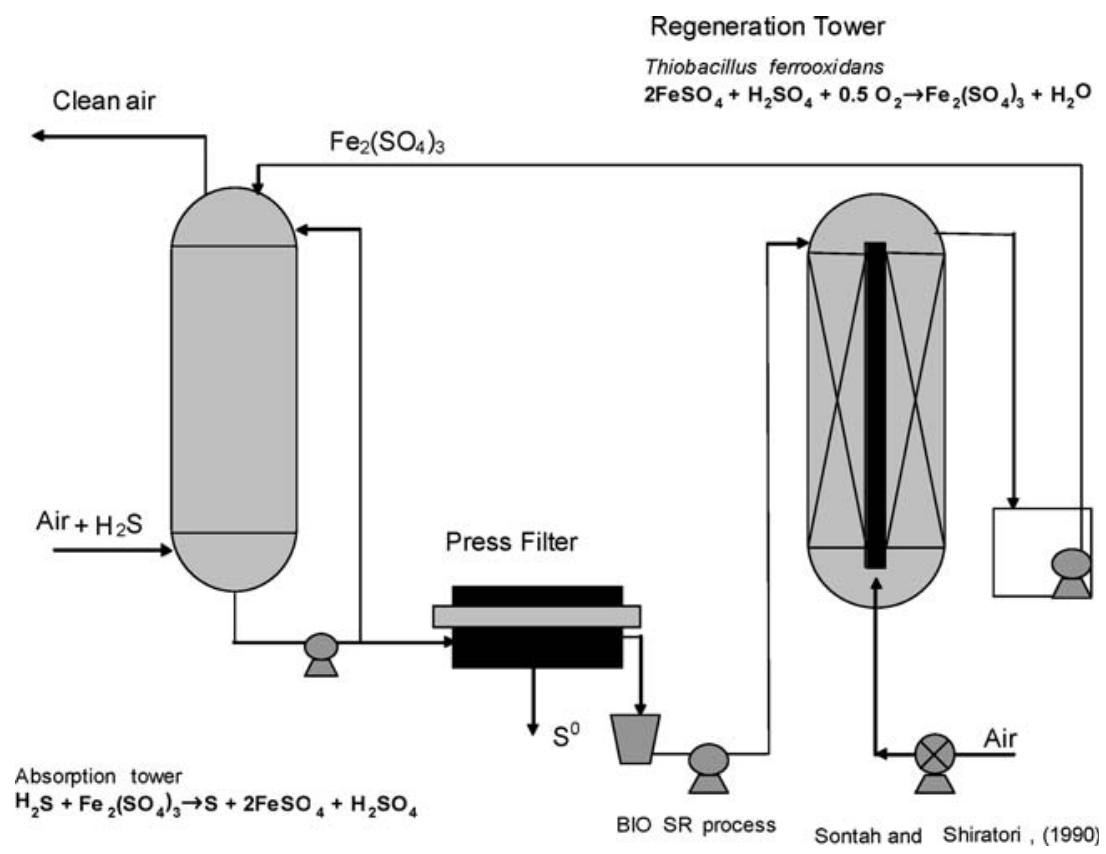

Figure 5. Schematic of the BIO-SR process.

the problems associated with other $\mathrm{H}_{2} \mathrm{~S}$ oxidation microbiological processes as $\mathrm{H}_{2} \mathrm{~S}$ does not have an inhibiting effect on Thiobacillus ferrooxidans and $\mathrm{SO}_{4}^{2-}$ is not accumulated in the medium. (Satoh et al. 1988; Asai et al. 1990 and Sontah et al. 1990).

\subsubsection{Mixture of Thiobacillus and} heterotrophous microorganisms

In the Biocyd process, polluted air passes through a packed reactor in which a biofilm mixed culture of sulfooxidants as well as heterotrophic bacteria has been developed (Torres et al. 1993; Revah et al. 1995; Hugler et al. 1999). The reactions are, at the beginning, a partial oxidation of sulfide to sulfur: If the levels of oxygen are high and sulfur is not removed from the reactor, the reaction continues to sulfate:

$$
\begin{gathered}
2 \mathrm{H}_{2} \mathrm{~S}+\mathrm{O}_{2} \rightarrow 2 \mathrm{~S}^{0}+2 \mathrm{H}_{2} \mathrm{O} \\
2 \mathrm{~S}^{0}+2 \mathrm{H}_{2} \mathrm{O}+3 \mathrm{O}_{2} \rightarrow 2 \mathrm{H}_{2} \mathrm{SO}_{4}
\end{gathered}
$$

Figure 6 shows a diagram of this arrangement.

\section{Biogas as an energy source}

Biogas is a useful energy source that can be and aid to diminish the operation costs involved in the wastewater and sludge conditioning processes. Nevertheless, as already mentioned, domestic wastewater has such a low COD concentration that biogas reuse is sometimes economically unfeasible. In any case, biogas produced in anaerobic reactors, if it is not used, should be flared or treated in order to avoid venting it to the atmosphere.

Hence, two mayor topics are considered in this section:

- Raw biogas treatment in order to obtain a certain quality accordingly to the required standards for driving gas engines or biogas fired boilers.

- Raw biogas conditioning in order to obtain a biogas quality for a proper burning in a flare if its reuse has been found to be economically unfeasible.

Biogas produced in anaerobic digestion processes can be used for several purposes:

- direct gas use in boilers or heating devices, 


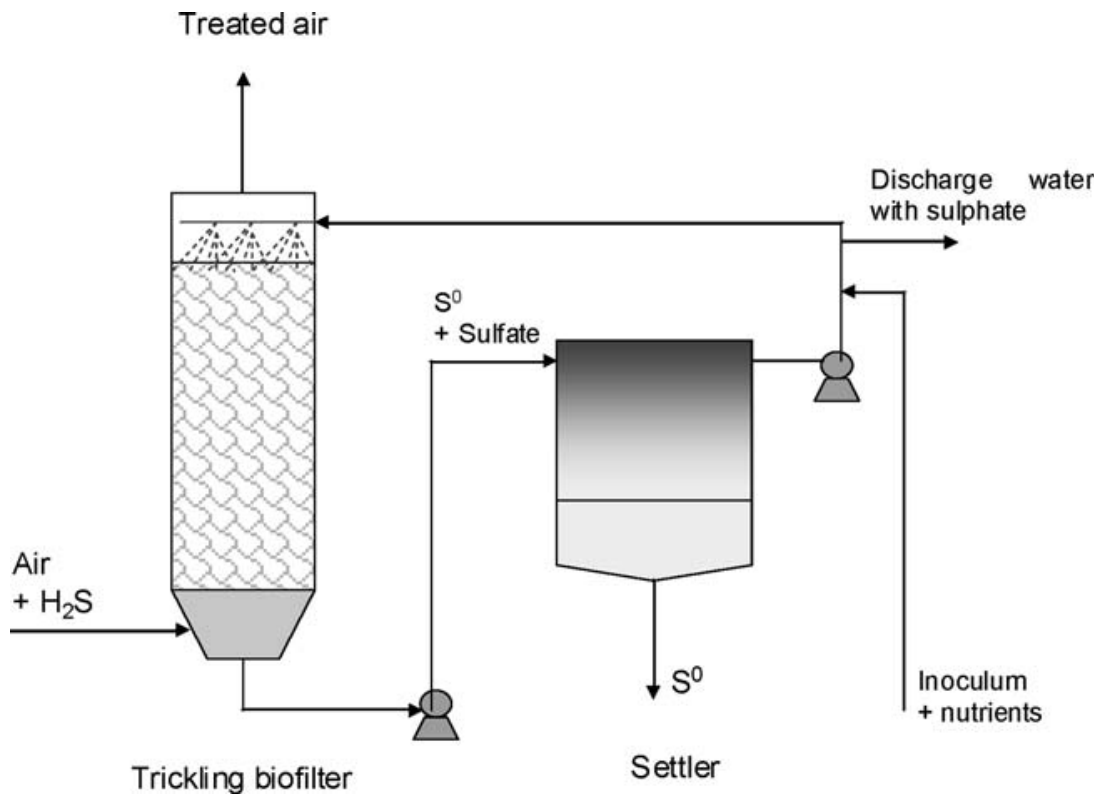

Figure 6. Schematic of the BIOCYD process.

- fuel for an engine directly coupled to a power generator,

- cogeneration of heat and power,

- upgrade of biogas to specifications of natural gas in order to run motor vehicle engines or to supply a local gas network.

In all these cases, water and $\mathrm{H}_{2} \mathrm{~S}$ removal should be provided. In addition, if the gas is to be used in gas engines, or if it is upgraded to a natural gas quality, the biogas should be enriched with methane, so $\mathrm{CO}_{2}$ should be removed as well. Table 3 lists typical requirements for gas engines.

Table 3. Typical requirements for gas engines (AD-NETT 2000)

\begin{tabular}{lll}
\hline Component & Dimension & Range \\
\hline $\begin{array}{l}\text { Energy content } \\
\text { Variation of energy }\end{array}$ & $\mathrm{MJ} / \mathrm{m}^{3}$ & $13-21$ \\
$\quad$ content & & $0-2$ \\
$\begin{array}{l}\text { Maximum temperature } \\
\text { feed }\end{array}$ & ${ }^{\circ} \mathrm{C}$ & $40-60$ \\
Minimum delivery & $\mathrm{mbar}$ & $25-80$ \\
$\quad$ pressure & & \\
$\begin{array}{l}\text { Biogas humidity } \\
\mathrm{H}_{2} \text { S content }\end{array}$ & $\mathrm{mg} / \mathrm{m}^{3}$ & $<70-80$ \\
Chloride and fluor (total) & $\mathrm{mg} / \mathrm{m}^{3}$ & $<60-80-2000$ \\
\hline
\end{tabular}

At present, no common standard has been defined for biogas upgrading to natural gas, but it can be assumed that the European standards shall be the guidelines for most countries. Nevertheless, methane concentration should be at least $95 \%$ and $\mathrm{H}_{2} \mathrm{~S}$ concentration should be kept below $5 \mathrm{mg} / \mathrm{m}^{3}$. However, quality requirements for vehicle fuel from biogas may not be the same in different countries.

\subsection{Biogas treatment requirements}

The treatment degree of raw biogas will differ according to the type of biogas end use. Treatment procedures, already discussed in the previous section, should also be selected depending on the biogas flow. Table 4 shows some typical applications:

\subsection{Biogas storage prior to its use}

At the site of any anaerobic digestion facility, two gas streams are produced that need treatment: biogas and flue gas (headspace in reactor, tanks and ventilation devices). Biogas that is produced as an end product in anaerobic digesters is normally stored and utilized on site. Some medium and large scale industrial wastewater treatment plants with an anaerobic reactor as the 
Table 4. Different treatment degrees for biogas utilization (adapted from Nyns \& Thomas (1998))

\begin{tabular}{lllll}
\hline Type of end-use & Removal of water & Removal of $\mathrm{CO}_{2}$ & Removal of $\mathrm{H}_{2} \mathrm{~S}$ & Pressure requirements (bars) \\
\hline $\begin{array}{l}\text { Electrical power generator } \\
\text { Motor, Turbine }\end{array}$ & $\mathrm{P}-\mathrm{C}$ & $\mathrm{N}-\mathrm{P}-\mathrm{C}$ & $\mathrm{P}-\mathrm{C}$ & \\
Thermal power & $\mathrm{P}$ & $\mathrm{N}$ & $\mathrm{N}-\mathrm{P}-\mathrm{C}$ & \\
Co-generation & $\mathrm{P}-\mathrm{C}$ & $\mathrm{N}-\mathrm{P}-\mathrm{C}$ & $\mathrm{P}-\mathrm{C}$ & 200 \\
Vehicle fuel & $\mathrm{C}$ & $\mathrm{C}$ & $\mathrm{C}$ & $60-70$ \\
Natural gas for district heat & $\mathrm{C}$ & $\mathrm{C}$ & $\mathrm{C}$ & \\
\hline
\end{tabular}

$\mathrm{N}=$ no treatment; $\mathrm{P}=$ partial treatment; $\mathrm{C}=$ complete treatment.

main biological wastewater treatment process produce valuable biogas as a by-product that can be used as well. In most cases, biogas storage should be provided. This can be done in different types of storage facilities like:

- a water sealed, floating gasholder,

- a separate gas bag or a covered gasholder,

- the digester headspace with a foil membrane,

- a separate steel gas tank for high pressure storage.

According to the storage pressure, a more comprehensive classification can be as follows (Constant et al. 1989):

- Low pressure gasholders. The biogas pressure is kept below 50 mbar. Wet gasholders and dry gasholders are the common types of these low-pressure units.

- Medium pressure tanks. These are usually steel tanks where the biogas is storage at 10-20 bar pressure. Contrary to most low-pressure gasholders, the medium pressure tanks are of variable pressure and fixed volume.

- High pressure gas cylinders. Biogas is stored in steels cylinders of low volume (less than 501 ) at a pressure that varies from 150 to 350 bar.

Wet gasholders are generally floating covers or inverted vessels made out of steel. Some reactors or digester have a significant head space volume that may be used for gas storage. Typical volume ranges from 50 to $5,000 \mathrm{~m}^{3}$.

Dry, low-pressure gasholders are separated from the anaerobic reactor/digester; they are generally manufactured using a rubber or polymeric material. These gasholders may be installed under covers or housing structures in order to protect the plastic liner. The full storage volume ranges from 1 to $1,000 \mathrm{~m}^{3}$. Some gas holder arrangements are shown in Figure 7.

Many designers consider a one-day storage volume if the biogas facility is small. Otherwise, the storage volume is calculated according to the demand of the equipment if biogas is going to be used. Figure 8 shows an anaerobic lagoon cover that can be considered a low pressure wet gasholder.

\subsection{Biogas flaring}

If biogas utilization is not possible, biogas combustion with flares is required since direct emission of biogas into open air must be avoided for safety, health and environmental reasons. In fact, even if the anaerobic treatment plant has a biogas utilization facility, a flaring system should be installed in order to safely dispose of biogas during its maintenance and repairs.

When flaring is the only end point of biogas, storage may not be needed; however, some conditioning steps will still be required, depending on the biogas source and the environmental regulation at the particular place. In such case, conditioning steps could include defoaming, water and $\mathrm{H}_{2} \mathrm{~S}$ removal and even compression if biogas pressure at the flare inlet is too low.

Many countries have their own standards and regulations for emissions coming from biogas flaring facilities, being the standards adopted by the USA and the European Community the most advanced and comprehensive ones. For instance, the Dutch emission guidance (NER 3.5/90.1) considers the following restrictions for permanent flares (AD-NETT 2000):

- The outlet temperature of the flue gas has to be at least $900^{\circ} \mathrm{C}$.

- The residence time in the flare has to be at least $0.3 \mathrm{~s}$.

- The flare has to be of the 'closed type' (no visible flame). However, if flares are only being 

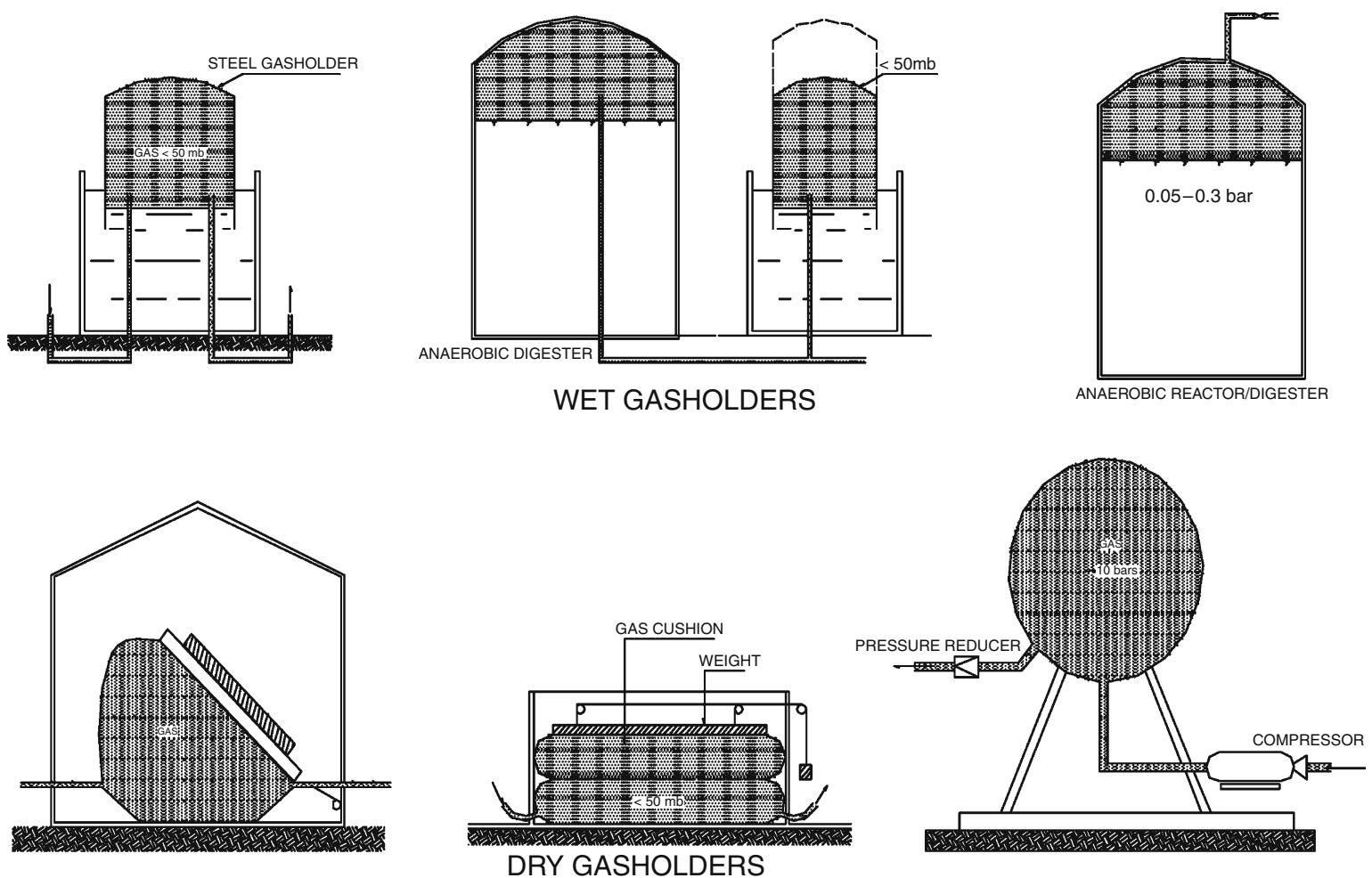

Figure 7. Different gasholder types (Constant et al. 1989).

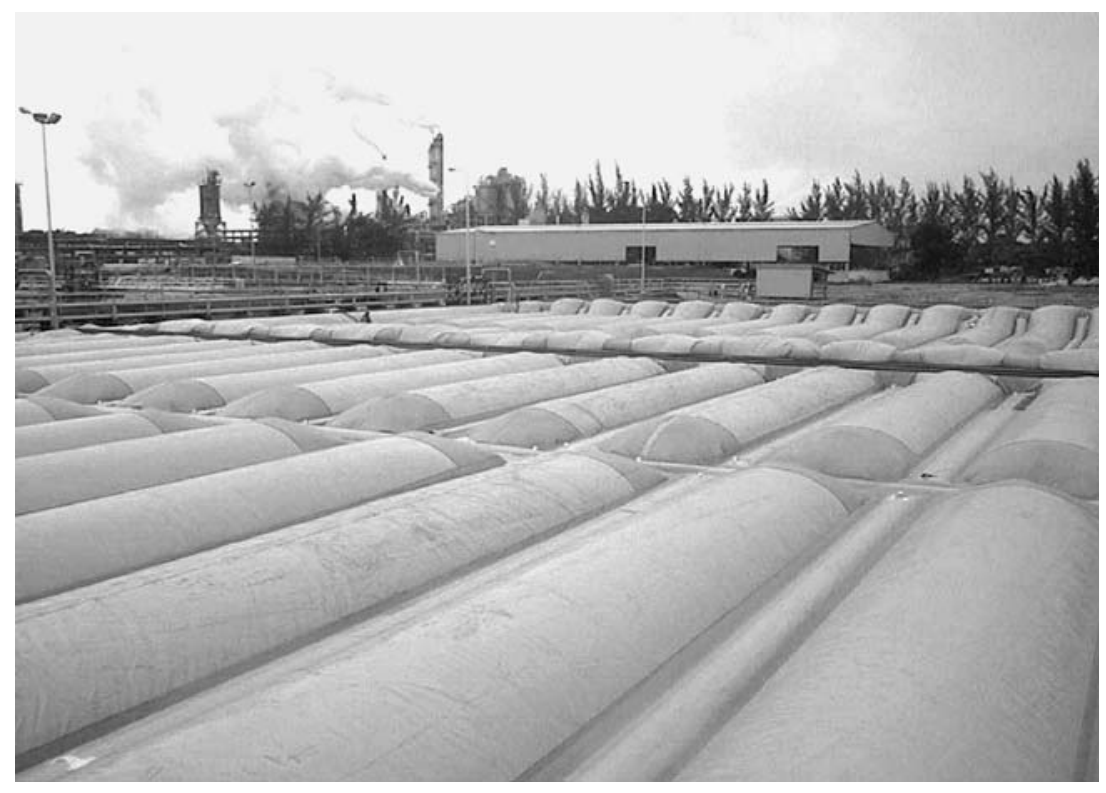

Figure 8. Anaerobic pond cover (low pressure, low profile wet gasholder).

used during periods of equipment maintenance, the use of a simple open or half-open flare is allowed.
- The maximum limit of $\mathrm{H}_{2} \mathrm{~S}$ and other organic sulfur compounds in the biogas to be flared is 50 ppmv. If this limit is exceeded, sulfur has to 

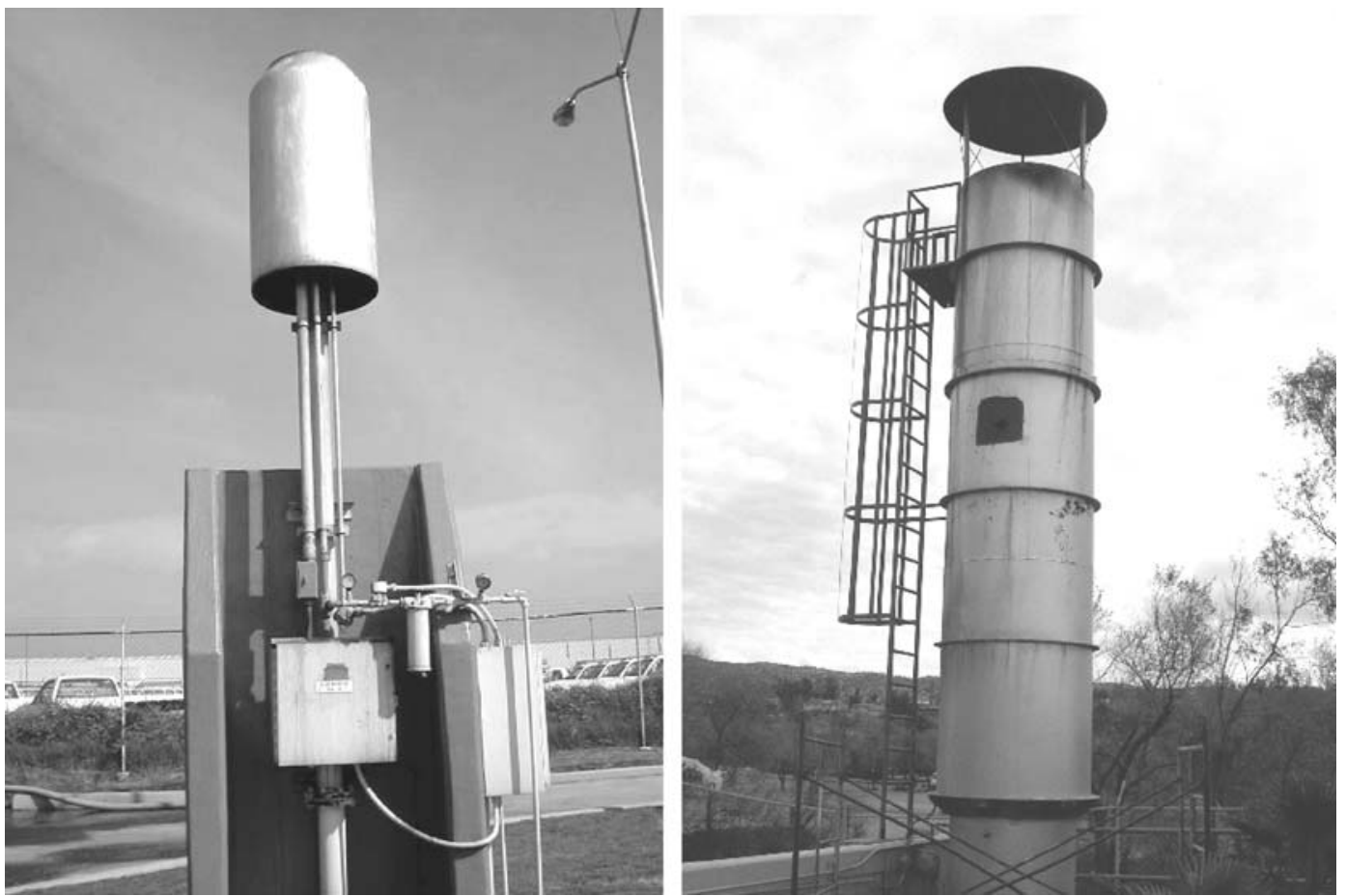

Figure 9. Open biogas flare (left) and enclosed biogas flare (right).

be removed from the biogas to less than 50 ppmv or a removal efficiency of at least $98 \%$. To prevent the formation of dioxins, the halogenated hydrocarbons content has to be lower than $150 \mathrm{mg} / \mathrm{m}^{3}$.

Totally enclosed flares are very expensive, mainly due to its refractory material used as an inside covering, so open flares are commonly used in Third World countries. In spite of this fact, it is expected that in the near future flaring of biogas will be restricted to enclosed flares. Figure 9 shows the two flare types.

\subsection{Biogas piping and accessories}

The common accessories in a conventional biogas line may include the following elements (WPCF 1987):

- A pressure relief/vacuum relief valve at the anaerobic digester/reactor cover, paired up to a vertical flame arrester in order to avoid a spark from entering the digester/reactor.

- A foam separator tank to eliminate dust and small solid particles that are carried on along with the biogas. In these tanks, usually water is sprayed in order to carry solid particles down to the tank bottom, where they are evacuated on a regular basis. These separators are very useful when installed at the suction side of a roots-type biogas compressor in order to stop small particles from entering the equipment, causing problems related to excessive overheating.

- Apart from the foam separator, a sediment/ water trap intended to eliminate part of the high moisture content of the biogas. These traps are usually installed to provide additional safety by removing the remaining solids and liquid from the gas stream. They can be sufficient if the biogas solids or foam content is limited, as in anaerobic reactors treating municipal wastewater.

- A low pressure check valve. The check valves are recommended at every single biogas source lines in order to isolate them from the others if a general system collects from more that one production source.

- A biogas flow metering device. Nowadays the thermal mass flowmeter type is the most commonly used.

- A back pressure regulator with a horizontal flame arrester and thermal shut-off valve in order to avoid biogas flashbacks, located as 
close as possible (less than $3 \mathrm{~m}$ ) to the flame source (a flare, a boiler, etc.).

- A waste gas burner. As mentioned earlier, this burner can be of two types: open atmospheric flare or totally enclosed flare. The latter is the recommended one, although more expensive.

- As many manometers as required by the process. The usual type is the well column manometer, filled with oil with a specific gravity similar to water, or mercury for a higher pressure application. It is recommended to install at least two manometers: one at the biogas source and another one at the flare inlet.

It should be pointed out that water condensates along the biogas lines, so some drip traps must be installed in every point where water accumulation is expected. For instance, the water trapped by the sediment tank is usually eliminated on a regular basis using a manual drip trap. The horizontal flame arresters are heat dissipation units and also they accumulate water, so some manufacturers supply them with manual drip traps. It is recommended to install a drip trap at the lowest point of the line and at the base of the flare tube. This trap can be an automatic or manually operated unit.

A typical, fully equipped, biogas flaring system is shown in Figure 10. It should be pointed out that in many anaerobic reactors or digesters in developing countries much simpler arrangements are used. Adaptation to local conditions should be encouraged, as long as safety requirements are not compromised.

When sizing the gas piping and equipment, the following parameters should be considered (WPCF 1987):

- Biogas design flow at minimum, normal and maximum conditions. These data are mandatory to properly size biogas piping, equipment and storage facilities.

- Biogas pressure at the generation site. This is very important in order to determine if a compression step is required. Most open flares are specified to operate with an inlet pressure of 6 in $\mathrm{H}_{2} \mathrm{O}$ (at the very least). In the same way, most biogas boilers needs a minimum biogas pressure of 12 in $\mathrm{H}_{2} \mathrm{O}$ (fired tube boilers), or 4 in $\mathrm{H}_{2} \mathrm{O}$ (water flexible tube boilers) at the inlet connection.

- For a proper operation of an open flare, the minimum pressure at the flare outlet should be 2 in $\mathrm{H}_{2} \mathrm{O}$. This is a simple rule of thumb, so for a detailed calculation procedure it is recommended to refer to the technical literature about the subject.

- Pipe diameter, length and fitting. According to the Manual of Practice No. 8 (WEF 1999) the

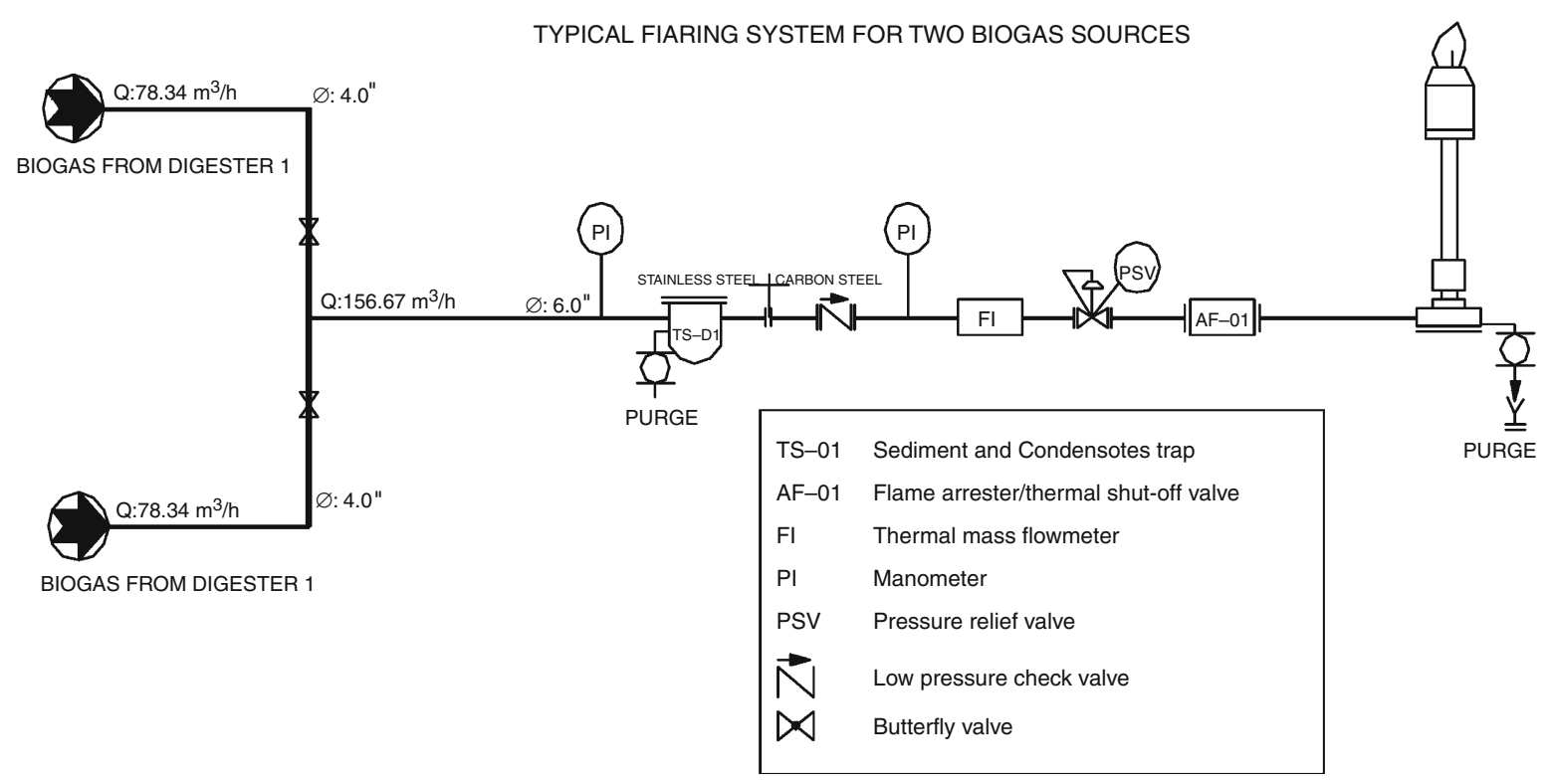

Figure 10. Typical flaring system for two biogas sources. 
piping should be sized with a maximum gas velocity below $3.7 \mathrm{~m} / \mathrm{s}$. This velocity will prevent liquid and solid carry-over that may damage equipment downstream. Additionally, the number of pipe bends and long piping runs should be minimized to reduce pressure losses.

The calculation procedures are described in other technical references beyond the scope of this work, but generally speaking they consider the following stepwise approach (WPCF 1987):

- Estimate the biogas production.

- Determine the operating pressure necessary for all gas utilization equipment.

- Select the line size necessary to meet the velocity requirements. Determine pressure losses through each piece of equipment in the line leading to the flare. The sum of the pressure required at the flare inlet and the pressure drop determines the minimum operating pressure necessary beneath the digester/reactor cover. Low pressure drop should be maintained across the entire system. Manufacturer manuals and catalogs should be consulted to determine the pressure drop at every accessory within the biogas line.

- In more complex systems, it is necessary to determine the minimum inlet pressures and pressure drops for each line before calculating the cover pressure. A gas storage device may be necessary to handle loads during periods of low gas production.

- In general terms, the pressure relief valve on the digester cover should be set to open at 0.5 in $\mathrm{H}_{2} \mathrm{O}$ below the maximum operating pressure. To ensure that the pressure relief valve operates at a completely closed position, the reactor/digester internal pressure should be at $80 \%$ of the pressure setting of that valve. For instance, if the valve is set at 13 in $\mathrm{H}_{2} \mathrm{O}$, then the internal system pressure should be no more than 10.5 in $\mathrm{H}_{2} \mathrm{O}$. Otherwise, the relief valve may not be completely losed.

- A pressure regulator valve is recommended to maintain a proper pressure at the flare inlet or at the gas utilization equipment. As a rule of thumb, the regulator valve will be set at a pressure calculated using the maximum system pressure (internal biogas pressure at the reactor/ digester) minus the pressure losses calculated for the whole piping and accessories in the system. When properly sized, the pressure regulator valve will usually have the following smaller nominal diameter taking the line diameter as reference.

Some additional rules of thumb are the following:

- All gas piping should be sloped a minimum of $2 \%$ for proper drainage. Drip traps should be located at all low points, and in long pipe runs.

- Flame arresters should be installed as close to the source of ignition as possible. Those arresters can be located at a maximum of $3 \mathrm{~m}$ upstream of the ignition source when used in accordance with UL standards. This is due to the limited capacity of arresters to dissipate the heat produced by the biogas combustion. The higher the biogas volume in the pipe, the more difficult to the arrester to dissipate energy, so flames may pass the arrester causing an explosion.

- A flame arrester should be specified in areas where there is a possibility of air entrance, such as relief valves and vents. Where there is an open flame or possible sparking, e.g., flares, boilers or engine-generators, additional protection utilizing thermal bypass shut-off valves, and pressure (explosion) relief valves should be specified along with the flame arrester.

\subsection{Safety considerations}

The main risks involved in the storage and utilization of biogas are due to the high flammability of methane if combined with air in the proper proportions. The low explosive level (LEL) for methane is $5 \%$, while the high explosive level (HEL) is $15 \%$. This means that a methane concentration as low as $5 \%$ is enough to cause an explosion if mixed with air. Conversely, a methane-oxygen gas mixture with a methane concentration higher than $15 \%$ will not have enough oxygen to burn.

Methane flammability is then the main concern for the specification of equipment, instrumentation and control elements within the anaerobic reactors/digesters area (biogas piping lines, biogas utilization equipment and flaring system).

According to Bradfer (2002), the safety standards that apply to biogas handling as a risky compound can be depicted as follows (Figure 11). 


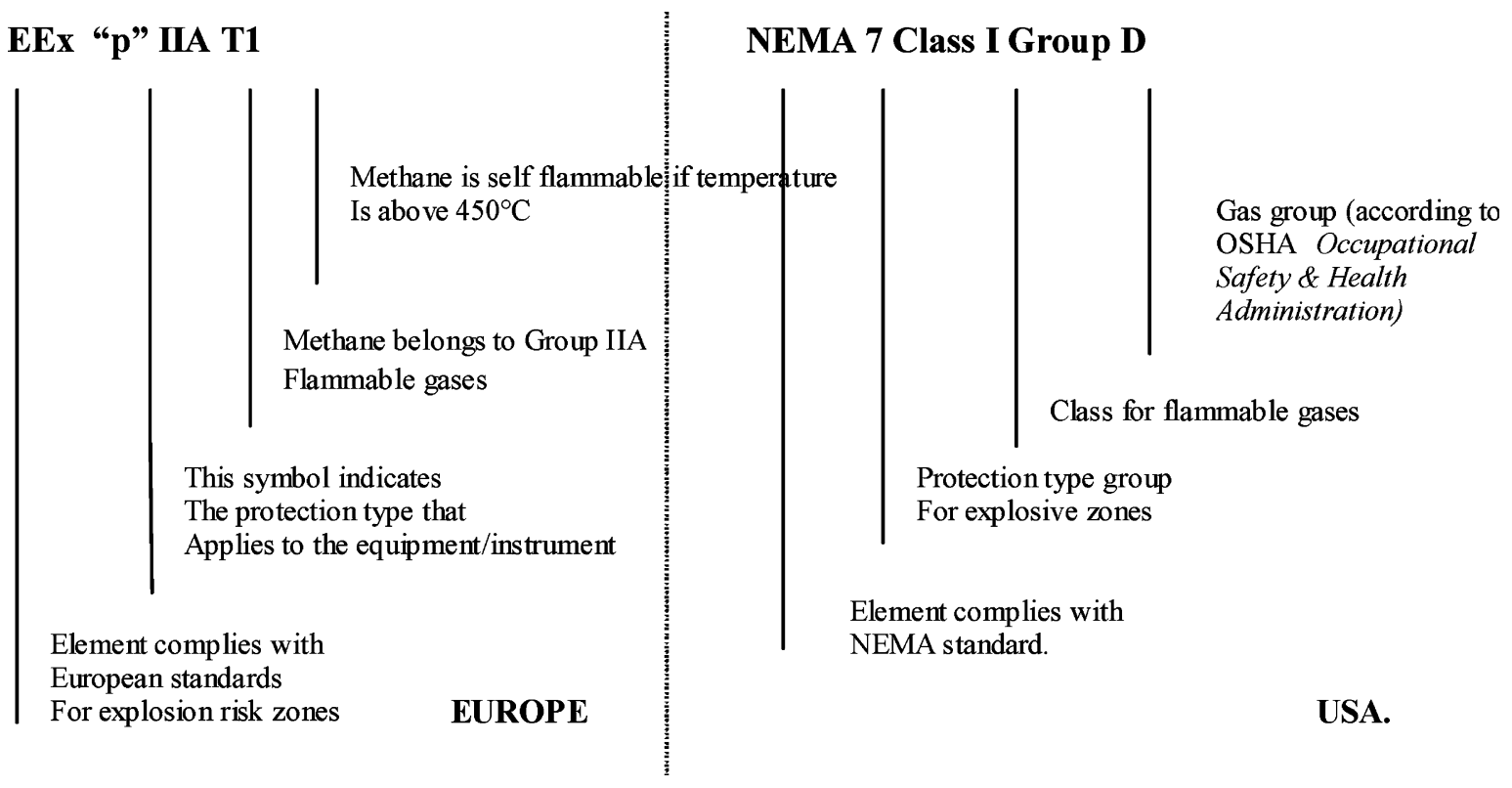

Figure 11. Biogas classification according to European and USA standards. Adapted from Bradfer (2002).

Every engineering procedure for the design and specification of any biogas handling system shall consider those standards as the safety reference system.

\section{Biogas as substrate (electron donor) for denitrification of wastewaters}

Nitrogen control is increasingly reinforced in developing countries, and it is the second step in wastewater treatment policies. As a result, municipal sewage treatment should now consider, in many cases, a proper removal of nitrogen and even phosphorous as well.

Anaerobic sewage treatment may be regarded as a suitable core technology for sustainable wastewater management and resource recovery (Lettinga et al. 1997). Several process arrangements have been proposed for nitrogen, phosphorous and sulfur removal, all considering an anaerobic or anoxic step (Metcalf \& Eddy 2003; Villaverde 2004). In must of these processes, an organic electron donor must be supplied. This is the case of denitrification, where raw wastewater, endogenous cell reserves or external carbon sources may fulfill that need (Morgan-Sagastume et al. 1994; Metcalf \& Eddy 2003).
Some integrated anaerobic/anoxic - aerobic processes has been proposed for nitrogen removal; some of them requires an external carbon source in order to reach a low effluent concentration of total nitrogen. Methanol, ethanol, acetic acid has been used for this purpose, with the drawback of their additional costs. Methane, a free, endogenous carbon source has been underestimated, as few research studies have been published on that subject (Davies 1973; Sollo et al. 1976; Rhee \& Fush 1978; Werner \& Kayser 1991; Thalasso et al. 1995; Houbron et al. 1999; Rajapakse \& Scutt 1999; Costa et al. 2000; Eisentraeger et al. 2001; Santos et al. 2004; Islas-Lima et al. 2004).

Even if some discussion still prevails on the biochemical pathways and the denitrification rates (Mason 1977; Costa et al. 2000; Islas-Lima et al. 2004), there is enough evidence that methane may be used as external carbon source for denitrification, achieving removal rates similar to those obtain with classical substrates, such as methanol or ethanol (Werner \& Kayser 1991; Thalasso et al. 1995; Houbron et al. 1999). The requirements for a proper denitrification process with methane are a good gas transfer to the liquid phase and a limited concentration of dissolved oxygen, around $1 \mathrm{mg} / \mathrm{L}$ (Werner 
\& Kayser 1991; Thalasso et al. 1995; Houbron et al. 1999; Costa et al. 2000).

The use of methane for nitrogen removal is another potential advantage of anaerobic resource recovery integrated technologies that still have to be validated in full scale plants. The resulting reduction in operational cost would be another advantage for the application of anaerobic sewage treatment in developing countries.

\section{Biogas and the Kyoto Protocol}

Biogas emissions from anthropogenic sources are a threat to the gaseous composition of the atmosphere and contribute to the greenhouse gases inventory. Livestock exploitations, rice production, sanitary landfills and waste organic treatment facilities are important sources of methane. This gas is being accumulated in the atmosphere at a higher rate than $\mathrm{CO}_{2}(0.6$ versus $0.4 \%$ per year for the $1984-1994$ decade) their concentration in the atmosphere being $1720 \mathrm{ppbv}$ and 350 ppmv, respectively for year 1994 (UNEP 1999).

For this and other reasons, the common practice of biogas venting at small- and medium-size anaerobic municipal wastewater treatment plants should be avoided. The potential application of modern and adapted anaerobic technologies in developing countries could be hindered if this aspect is not solved. On the other hand, a facility for biogas conversion to energy (electricity) may apply for the clean development mechanism (CDM) of the Kyoto Protocol. As a result, developing countries may implement sustainable technologies and receive an income for their fscertified emission reductions (CERs) from developed countries. The CDM is established in Article 12 of the Kyoto Protocol.

In order to register a specific project under the CDM, the concept of additionality should be met, as defined in the 2001 Marrakesh Accords. A CDM project should prove that it reduces anthropogenic greenhouse gases emissions below those levels that would have occurred if the project was not implemented. Moreover, the project developer should demonstrate that without the CDM, the project is not the most feasible economic option or that barriers can be surmounted if the CDM registration is obtained; this may be a long and complex process. CERs are sold between $€ 3$ and 10 per ton of $\mathrm{CO}_{2}$ equivalents, depending on the stage of the project cycle (UNEP 2005).

\section{Conclusions}

In order to favor a wider adoption of anaerobic process for municipal sewage in developing countries, odor control and biogas utilization/ disposal should be properly addressed. However, anaerobic sewage treatment should not be considered as an energy producer, unless a significant wastewater flow is treated.

$\mathrm{H}_{2} \mathrm{~S}$ is the most characteristic bad odor constituent in biogas and at the surroundings of anaerobic digesters and wastewater treatment facilities; many research works on odor control consider $\mathrm{H}_{2} \mathrm{~S}$ as the reference compound.

Treatment technologies options for biogas cleaning and odor control are relatively extensive. The choice of a particular technology should consider technical and economical factors as well as environmental and safety aspects. From a technical standpoint, variables such as stream (flow, temperature and humidity) and pollutant characteristics (composition, concentration, reactivity, solubility and biodegradability) have to be evaluated.

An important advantage of biological treatment methods over physical and chemical technologies is the fact that biological processes can be operated at local temperature and pressure, within a wide range of pollutants at medium to low concentrations. Biological purification facilities are also ecologically friendly and less expensive if compared with most physicalchemical treatments.

In most of small anaerobic municipal treatment plants, biogas is vented, transferring pollution from water to the atmosphere and contributing to the greenhouse gas inventory. To overcome this problem, biological processes, such as compost biofilters, should be developed for methane removal prior to biogas venting, considering the simplicity of this technology, in congruence with anaerobic treatment options. A methane and sulfide oxidizing bacterial consortium would make this small scale technology feasible. 
Further integration of anaerobic resource recovery processes can be accomplished if methane is used as electron donor for denitrification and nitrogen control purposes. Although this scheme must still be validated in full scale plants, the resulting reduction in operational cost would be another advantage for the application of anaerobic sewage treatment in developing countries.

Developers involved in biogas conversion to energy projects in developing countries may apply for the CDM of the Kyoto Protocol, increasing the economic feasibility of such projects through the marketing of CERs.

\section{References}

AD-NETT (2000) Anaerobic digestion of agro-industrial wastes: information networks. Technical summary on gas treatment. European Community Project FAIR-CT96-2083 (DG12-SSMI). Available at www.adnett.org

Allen ER \& Phatak S (1993) Control of organosulfur compound emissions using biofiltration: methyl mercaptan. In: Proceedings of the 86th Air and Waste Management Association Annual Meeting and Exhibition. June 13-18, Denver, Colorado, USA

Asai S, Konishi Y \& Yabu T (1990) Kinetics of absorption of hydrogen sulfide into aqueous ferric sulphate solutions. AICHE J. 36: 1331-1338

Bhatia SP (1978) Organosulfur emissions from industrial sources In: Nriagu J.O. (ed.), Sulfur in the Environment, Part I, John Wiley \& Sons, Canada

Bell K (1988) Heat transmission: thermal design of heat transfer equipment In: Perry R \& Green D (Eds) Perry's Chemical Engineering Handbook (pp 1020-1023). 6th edition, McGraw Hill, New York

Bielefeldt A (2001) Activated sludge and suspended growth bioreactors In: Kennes C \& Veiga MC (Eds) Bioreactors for waste gas treatment. (pp 215-254). Kluwer Academic Publishers, The Netherlands

Bradfer JF (2002) Safety risks related to biogas handling in a wastewater treatment plant. In: CD Proceedings of the XXVIII Interamerican Congress of Sanitary and Environmental Engineering (in Spanish). Interamerican Association of Sanitary and Environmental Engineering (AIDIS), October 27-31, Cancun, Mexico

Cadenhead P \& Sublette KL (1990) Oxidation of hydrogen sulfide by Thiobacilli. Biotechnol. Bioeng. 2: 201-203

Cadena FP \& Peters RW (1988) Evaluation of chemical oxidizers for hydrogen sulphide control. J. Water Pollut. Control Fed. 60: 1259-1263

Cardenas-Gonzalez B, Ergas S, Switzenbaum M \& Phillibert N (1999) Evaluation of full-scale biofilter media performance. Environ. Prog. 18: 205-211

Carlson DA \& Leiser CP (1966) Soil beds for the control of sewage odors. J. WPCF. May: 829-840

Chen KY \& Morris JC (1972) Kinetics of oxidation of aqueous sulphide by oxygen. Environ. Sci. Technol. 6: 529-537
Cho KS, Hirai M \& Shoda M (1992) Degradation of hydrogen sulfide by Xanthomonas sp. Strain DY44 Isolated from Peat. App. Environ. Microbiol. April: 1183-1189

Constant M, Naveau H, Ferrero GL \& Nyns EJ (1989) Biogas End-Use in the European Community. Elsevier Science Publisher, England

Corbitt RA (1990) Air quality control In: Corbitt RA (Eds) Standard Handbook of Environmental Engineering (pp 4100-4115). McGraw Hill, New York

Cork DJ \& Ma S (1982) Acid-gas bioconversion favors sulfur production. Biotechnology and Bioengineering Symp. 12: 285-290

Costa C, Dijkema C, Friedrich M, García-Encina P, Fernández-Polanco F \& Stams JM (2000) Denitrification with methane as electron donor in oxygen-limited bioreactors. Appl. Microbiol. Biotechnol. 53 (6) 754-762

Davies TR (1973) Isolation of bacteria capable of utilizing methane as a hydrogen donor in the process of denitrification. Water Res. 7: 575-579

Eisentraeger A, Klag P, Vansbotter B, Heymann E \& Dott W (2001) Denitrification of groundwater whit methane as sole hydrogen donor. Water Res. 35 (9) 2261-2267

Ergas S (2001) Membrane bioreactors In: Kennes C \& Veiga MC (Eds) Bioreactors for Waste Gas Treatment. (pp 163-177). Kluwer Academic Publishers, Dordrecht, The Netherlands

Fernández Polanco F, Martínez B, Olmedo F \& García del Valle J (1996) Removal of $\mathrm{H}_{2} \mathrm{~S}$ using a chemical scrubber and biologica 1 oxidation. In: Proceedings IV Workshop and Seminar on Anaerobic Wastewater Treatment in Latin America (in Spanish), November 19-22, Bucaramanga, Colombia

Houbron E, Torrijos M \& Capdeville B (1999) An alternative use of biogas applied at the water denitrification. Water Sci. Technol. 40 (8) 115-122

Islas-Lima S, Thalasso F \& Gómez-Hernández J (2004) Evidence of anoxic methane oxidation coupled to denitrification. Water Res. 38: 13-16

Kennes C, Veiga C \& Prado O (2001) Non biological treatment technologies In: Kennes C \& Veiga MC (Eds) Bioreactors for Waste Gas Treatment. (pp 17-46). Kluwer Academic Publishers, Dordrecht, The Netherlands

Lang ME \& Jager RA (1992) Odor control for municipal sludge composting. BioCycle, August: 76-85

Lettinga G, Hulshoff Pol LW, Zeeman G, Field J, van Lier JB, van Bunsen JCL, Janssen AJH \& Lens P (1997) Anaerobic treatment in sustainable environmental production concepts. In: Proceedings of the 8th Conference on Anaerobic Digestion, Japan. 1:32-39

Hugler W, Acosta C \& Revah S (1999) Biological removal of carbon disulfide from waste air streams. Environ. Prog. (AICHE) 3: 173-177

Mansfield LA, Melnyk PE \& Richardson GC (1992) Selection and full scale use of a chelated iron absorbent for odor control. Water Environ. Res. 64: 120-127

Martínez CP \& Zamorano JP (1996) Practical experience on anaerobic treatment and odor control in a yeast factory. In: Proceedings IV Workshop and Seminar on Anaerobic Wastewater Treatment in Latin America (in Spanish), November 19-22, Bucaramanga, Colombia

Mason I (1977) Methane as carbon source in biological denitrification. J WPCF 49: 855-857

Merck (1996) The Merck Index. 12th edition, Merck \& Co. Inc., USA

Metcalf \& Eddy Inc. (2003) Wastewater Engineering: Treatment and Reuse. 4th edition, McGraw Hill, New York 
Morgan-Sagastume JM, Jiménez B \& Noyola A (1994) Anaerobic-anoxic-aerobic process with recycling and separated biomass for organic carbon and nitrogen removal from wastewater. Environ. Technol. 15: 233-243

Morgan-Sagastume JM, Ergas S, Noyola A (2003a) Changes in physical structure of a compost biofilter treating $\mathrm{H}_{2} \mathrm{~S}$. J. Air Waste Manag. Assoc. 53: 1011-01021

Morgan-Sagastume JM, Revah S \& Noyola A (2003b) Pressure drop and gas distribution in compost based biofilters: media mixing and composition effects. Environ. Technol. 24: 797807

Mukhopadhyay N \& Moretti EC (1993) Current and Potential Future Industrial Practices for Reducing and Controlling Volatile Organic Compounds. Center for Waste Reduction Technologies, American Institute of Chemical Engineers, New York

Noyola A (2004) Anaerobic digestion applied to municipal wastewater treatment: facts and limitations of an adapted technology for Latin America. In: CD Proceedings 77th Annual Technical Exhibition and Conference WEFTEC, October 2-6, Water Environmental Federation, New Orleans, USA

Noyola A, Capdeville B \& Roques H (1988) Anaerobic treatment of domestic sewage with a rotating-stationary fixed film reactor. Water Res. 12: 1585-1592

Nyns EJ \& Thomas S (1998) Biogas from waste and wastewater treatment. Renewable Energies Series, Belgium Ver. 2. Lior CD Collection

Ongcharit C, Shah YT \& Sublette JL (1990) Novel Immobilized Cell Reactor for Microbial Oxidation of $\mathrm{H}_{2} \mathrm{~S}$. Chem. Eng. Sci. 45: 2383-2389

Planker TW (1998) Masking and odor neutralization In: Rafson HJ (Eds) Odor and VOC control Handbook (pp 818824). McGraw Hill, New York

Pomeroy R (1982) Biological treatment of odorous air J. WPCF 54: 1541-1545

Qasim RS (1999) Wastewater Treatment Plants: Planning, Design and Operation. Technomic Publishing Co, Lancaster $\mathrm{Pa}$, USA

Rands MB, Cooper DE, Woo CP, Fletcher GC \& Rolfe FK (1981) Compost filters for $\mathrm{H}_{2} \mathrm{~S}$ removal from anaerobic digestion and rendering exhausts. J. WPCF 53: 185-189

Revah S, Hinojosa A \& Morales V (1995) Air biodesulphurisation in process plants, in Bioremediation. OECD Documents, Paris, France 569-576 The Tokyo'94 Workshop

Revah S \& Morgan-Sagastume JM (2005) Methods for odor and VOC control In: Shareefdeen Z \& Singh A (Eds) Biotechnology for Odor and Air Pollution Control. (pp 2964). Springer-Verlag, Heidelberg, Germany

Revah S \& Noyola A (1996) Biotechnology markets in Mexico and opportunities for university and industry collaboration (in Spanish) In: Galindo E (Eds) Frontiers in Biotechnology and Bioengineering. (pp 121-136). Mexican Society of Biotechnology and Bioengineering, Mexico

Rhee G \& Fuhs WG (1978) Wastewater denitrification with one carbon compounds as energy source. J WPCF 50: 2111-2119

Rudolf von Rohr PH \& Ruediger P (2001) Rotating biological contactors In: Kennes C \& Veiga MC (Eds) Bioreactors for Waste Gas Treatment. (pp 201-214). Kluwer Academic Publishers, Dordrecht, The Netherlands
Santos SG, Varesche MBA, Zaiat M \& Foresti E (2004) Comparison of methanol, ethanol and methane as electron donors for dentrification. Environ. Eng. Sci. 21: 313-320

Satoh H, Yoshizawa J \& Kamentani S (1988) Bacteria help desulfurize gas. Hydrocarb. Process. Int. Ed. 76: 76D-76F

Särner E (1990) Removal of sulphate and sulphite in an anaerobic trickling (ANTRIC) filter. Water Sci. Tech. 22: 395-404

Smet E \& Van Langenhove H (1998) Abatement of volatile organic sulfur compounds in odorous emissions from the bioindustry. Biodegradation 9: 273-284

Sollo FW, Müller HF \& Larson TE (1976) Denitrification of wastewater effluents with methane. J. WPCF 48 (7) 1840-1842

Sontah H \& Shiratori $\mathrm{T}$ (1990) Method of Treating $\mathrm{H}_{2} \mathrm{~S}$ Containing Gases. US Patent 4931262

Sublette KL \& Sylvester ND (1987) Oxidation of hydrogen sulfide by mixed cultures of Thiobacillus denitrificans and heterotrophs. Biotechnol. Bioeng. 29: 759-761

Thalasso AF, Vallecillo A, García-Encina P \& FernándezPolanco F (1995) The use methane as a sole carbon source for water denitrification. Water Res. 31: 55-60

Thomson RB (1980) Catalytic Removal of Hydrogen Sulfide from Gases. US Patent No 4189462

Torres M, Revah S, Hinojosa A, Paez F \& Morales V (1993) Process for the Elimination of Sulphur Compounds Present in a Gas Mixture, US Patent 5,236,677

UNEP (1999) Understanding climate change: a beginners guide to the UN Framework Convention and its Kyoto Protocol. United Nations Environmental Program, Climatic Change Secretariat (35 pp), Geneva

UNEP (2005) Finance for carbon solutions, CEO Briefing, United Nations Environmental Program Finance Initiative (8 pp), Geneva

Van Groenestijn JW \& Hesselink PG (1993) Biotechniques for air pollution control. Biodegradation 4: 283-301

Van Groenestijn JW (2001a) Bioscrubbers In: Kennes C \& Veiga MC (Eds) Bioreactors for Waste Gas Treatment. (pp 133-162). Kluwer Academic Publishers, Dordrecht, The Netherlands

Van Groenestijn JW (2001b) Combined advanced oxidation and biodegradation In: Kennes C \& Veiga MC (Eds) Bioreactors for waste gas treatment. (pp 179-200). Kluwer Academic Publishers, Dordrecht, The Netherlands

Villaverde S (2004) Recent developments on biological nutrient removal processes for wastewater treatment. Rev. Environ. Sci. Bio/Technol. 3: 171-183

Waldrop RE (1998) Condensation In: Rafson HJ (Eds) Odor and VOC Control Handbook (pp 825-830). McGraw Hill, New York

Webster TS, Devinny JS, Torres EM \& Barrai SS (1996) Biofiltration of odors, toxics and volatile organic compounds from publicly owned treatment works. Environ. Prog. 15: $141-147$

WEF (1999) Wastewater Treatment. 3 Water Environment Federation, USA Manual of Practice 8

Werner M \& Kayser R (1991) Denitrification with biogas as external carbon source. Water Sci. Technol. 23 (4-6) 701-708

West JR (1983) Sulfur Recovery In: Grayson M \& Eckroth D (Eds) Encyclopedia of Chemical Technology Kirk Othmer 22 (pp 267-297). John Wiley \& Sons, New York

WPCF (1987) Anaerobic Sludge Digestion. 2 Water Pollution Control Federation, USA Manual of Practice No. 16 